\title{
Article \\ Effect of Well Orientation on Oil Recovery from Waterflooding in Shallow Green Reservoirs: A Case Study from Central Africa
}

\author{
Jackson Waburoko ${ }^{1}$, Congjiao Xie ${ }^{1, *}$ and Kegang Ling ${ }^{2}$ \\ 1 Key Laboratory of Tectonics and Petroleum Resources, Ministry of Education, \\ China University of Geosciences, Wuhan 430074, China; jacwabs@gmail.com \\ 2 Department of Petroleum Engineering, University of North Dakota, Grand Forks, ND 58202-6116, USA; \\ kegang.ling@UND.edu \\ * Correspondence: cxie2004@cug.edu.cn; Tel.: +86-189-7144-6913; Fax: +86-27-6788-3051
}

check for updates

Citation: Waburoko, J.; Xie, C.; Ling, K. Effect of Well Orientation on Oil Recovery from Waterflooding in Shallow Green Reservoirs: A Case Study from Central Africa. Energies 2021, 14, 1223. https://doi.org/ $10.3390 /$ en14051223

Academic Editor: Michael Kühn

Received: 30 December 2020

Accepted: 11 February 2021

Published: 24 February 2021

Publisher's Note: MDPI stays neutral with regard to jurisdictional claims in published maps and institutional affiliations.

Copyright: (c) 2021 by the authors. Licensee MDPI, Basel, Switzerland. This article is an open access article distributed under the terms and conditions of the Creative Commons Attribution (CC BY) license (https:// creativecommons.org/licenses/by/ $4.0 /)$.

\begin{abstract}
Recovery efficiency is a key factor in decision-making in oil and gas projects. Although structural setup and well type considerably influence waterflood recovery, few studies have explored the performance of highly deviated wells during the waterflooding of complex shallow reservoirs. Here, we applied numerical simulations to investigate the performance of vertical, horizontal, multilateral, and highly deviated wells during waterflooding of complex shallow reservoirs using the J1 Oilfield as a case study. Recovery efficiencies of $31 \%, 33 \%, 31 \%$, and $26 \%$ could be achieved for vertical, horizontal, multilateral, and highly deviated wells, respectively. The gas production rate was 39\% higher in the vertical wells than in the other types. Highly deviated wells yielded the highest water-cut $(80 \%)$ over a short period. Highly deviated wells delivered the least production, and, despite branching laterals, multilateral wells were also not the most productive. Our results provide insights into the performance of different well types during the waterflooding of green heterogeneous non-communicating reservoirs and present an example of the successful practical application of waterflooding as an initial recovery mechanism when oil is near the bubble point. This study indicated that multilateral wells are not a panacea in reservoir development. Highly deviated wells are the ideal choice for the shallow, heterogeneous non-communicating reservoirs when economic and environmental impact are considered in decision-making. Well design should be a case-by-case study considering reservoir characteristics, economics, and environment impact.
\end{abstract}

Keywords: waterflooding; numerical simulation; well orientation; recovery efficiency; green shallow reservoir; non-communicating layers

\section{Introduction}

Energy sources, such as fossil fuels (especially oil and natural gas), are used in $96 \%$ of the commodities we use on a daily basis [1]. As oil prices have collapsed in recent years, enhanced oil recovery from existing reservoirs poses a lower risk than wildcat drilling to find new reservoirs. The oil and gas industry has witnessed an upsurge in measures aimed at increasing the oil recovery from green reservoirs [2-4]. As part of these initiatives, waterflooding has been widely adopted as the cheapest form of recovery [5-10]. However, different factors affect the overall performance of this method [11-13], including the structural setup of the reservoir and well type [14,15]. Thus, selecting the most suitable well type for waterflooding is essential.

Although vertical wells are commonly targeted in the early phases of drilling, more than $60 \%$ of wells currently being drilled are horizontal. Horizontal wells can (i) improve productivity, (ii) improve intersection with vertical-fracture networks, (iii) reduce gas and water coning, and (iv) increase sweep efficiency. Due to the improvement in trajectory design, the availability of bottom hole sensors, and the advancement of measuring-whiledrilling (MWD) tools [16-19], well trajectories have become increasingly complex. For example, highly deviated and multilateral wells can penetrate more discrete compartments 
in complex reservoirs, compared with conventional wells. Such new developments require the precise identification of the most suitable well type (i.e., vertical, horizontal, multilateral, or highly deviated) for each waterflood design. Previous studies have examined the relationships between well type and oil productivity in different environments. For example, Edwards (2017) found that horizontal wells outperform vertical wells in thin formations [20], whereas Pieters and Al-Khalifa (1991) reported that both vertical and horizontal wells have similar recoveries in layered carbonate reservoirs [21]. Elyasi (2016) showed that for fractured reservoirs, multilateral wells have better recoveries than vertical wells, whereas deviated wells outperform horizontal wells [22]. Ekebafe et al. (2019) reported that horizontal wells outperform deviated wells in unconsolidated formations [23]. Using a Dykstra-Parsons model extension, Muradov et al. (2018) verified that conventional wells perform better in stratified heterogeneous reservoirs with non-communicating layers [24]. Furthermore, Pieters and Al-Khalifa (1991) reported that neither horizontal nor multilateral wells guarantee improved oil recovery [21]. Zadravec and Brkić (2020) discussed a unique approach to enhance oil recovery through natural dump flooding well [25]. Intelligent completion has been installed in water injector inside the oil reservoir in the western Persian/Arabian Gulf to allow more efficient production of oil. On the basis of the successful application in this field, the authors evaluated the possibility of applying natural water dump flood in a Croatian oil field.

Despite the volume of published literature [26-38] on the recovery efficiencies of different well types, to the best of our knowledge, there has been no research on the performance of highly deviated wells in the highly heterogeneous shallow reservoirs of the Central African Rift Valley region, which are significantly different from most moderate-depth to deep reservoirs in other parts of world. This is because of (i) the complications associated with drilling along a precise path within an inclined path, (ii) difficulties encountered in preventing sand influx, and (iii) challenges encountered during screen installation for sand production control, which render directional drilling more difficult and time-consuming for complex reservoirs.

The J1 Oilfield in the Central African Rift Valley region is a newly discovered oilfield with no historical data. B27 is one of three main oil-bearing reservoirs (along with B30 and B25), separated by layers of shales with non-communicating heterogeneous reservoirs and shallow burial depths (500-800 m). In addition to areal compartmentalization via faulting, pressure data indicate vertical disconnections in the oil pools. Moreover, the presence of a primary gas cap and oil near the bubble point implies that a pressure maintenance scheme is required for initial oil production; hence, waterflooding should be considered. However, the selection of a suitable well type for maximum recovery remains a challenge. Our literature review indicates that horizontal and multilateral wells are not necessarily better than vertical or deviated wells for all reservoirs or vice versa and that well type should be considered on a case-by-case basis. The selection of an appropriate well type or combination for a specific reservoir should mainly depend on reservoir properties, which impact the oil production and oil field development/production cost. In terms of the J1 Oilfield, the selection of well type is further complicated because the field is located in an ecologically sensitive area that requires a minimal environmental footprint. Thus, the target reservoir must be assessed from a different surface location while avoiding complex fault structures in the vertically disconnected sand bodies. These limitations indicate that highly deviated wells would be a better option than vertical and horizontal wells. Furthermore, the lower drilling-design cost for highly deviated wells would also render them a better option than multilateral wells for the study area, if considering all other aspects including cost reduction and reduced environmental footprint. However, the objective of this study was to investigate the performance of different well types: vertical, horizontal, multilateral, and highly deviated wells, during waterflooding of complex shallow reservoirs using the J1 Oilfield and B27 reservoir as a case study.

We used the Petrel software and ECLIPSE black oil simulator to characterize and model the B27 reservoir using published and unpublished site-specific data obtained from 
seismic surveys, well logs, and measurements from repeat formation tester (RFT) tools. In addition to being the first study of its kind in this region, the results of this study provide further insights into the recovery performance of highly deviated wells, compared with those of other well types, and the waterflooding of reservoirs where oil is near the bubble point. Our results provided a reference for field with similar geological setting. After economic and environmental impact analysis, this study found that highly deviated wells are a better option. This is because although the oil production from highly deviated wells is slightly lower than other cases, the footprint (environmental impact) is much smaller. This investigation also indicated that multilateral wells are not always the best candidate for oil and gas field development. Every well type has its own advantages and disadvantages in oil and gas development and production. Properties of oil and gas and reservoir characteristics play a key role in selecting the appropriate well type. A thorough study of field, design of well, simulation, production forecast, and economic analysis are necessary for field evaluation and production plan. The step-by-step procedure illustrated in this paper provided a valuable guideline to oil field development.

\section{Methodology}

Using well logs and seismic data obtained from field reports and repeat formation tester (RFT) tools, we developed a three-dimensional (3-D) geological model, covering the full extent of the study field using a commercial software. Figure 1 illustrates the workflow of the proposed model, as explained in the following sections.

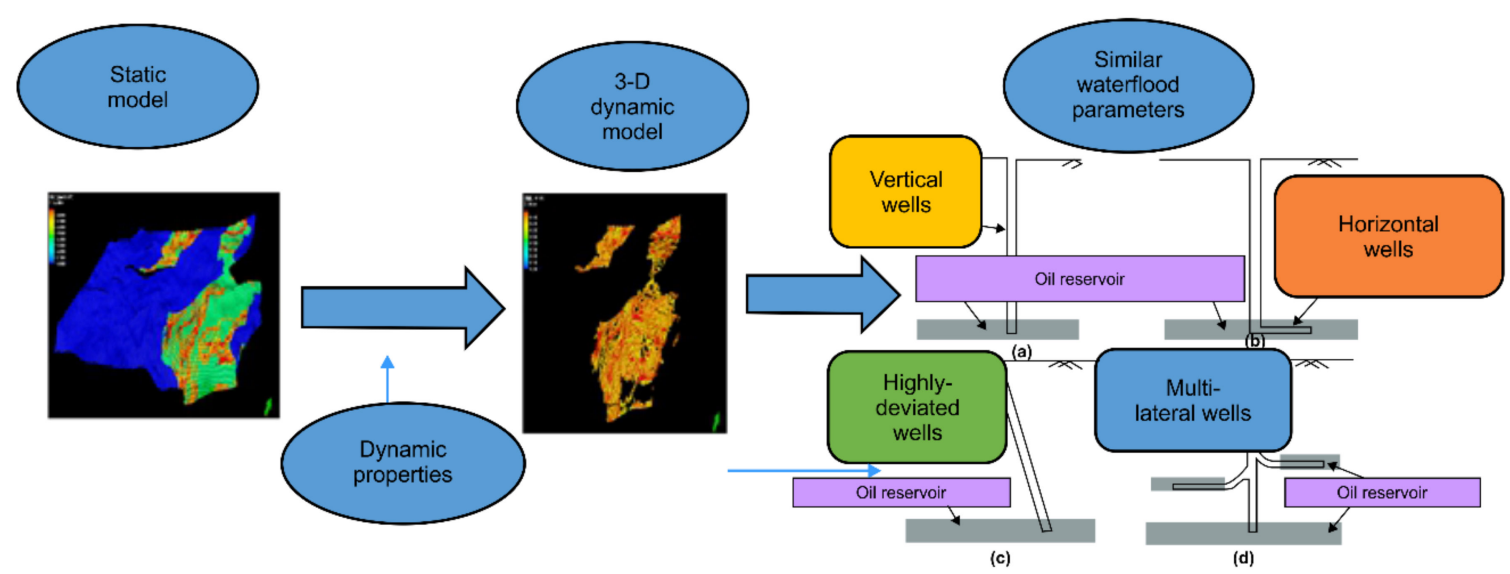

Figure 1. Summary of the workflow in the proposed model. Illustrations; (a), (b), (c), and (d) represent the different well types i.e., vertical, horizontal, highly deviated, and multilateral, respectively.

\subsection{Geological Setting}

The South Lokichar Basin is a Cenozoic sedimentary basin in Kenya that forms part of the East African Rift system (Figure 2). The basin is approximately $80 \mathrm{~km}$ long and $25 \mathrm{~km}$ wide, with a maximum depth exceeding $7 \mathrm{~km}$ [39]. Reservoirs in the basin are of middle Miocene age and were deposited under a fluvial-lacustrine regime punctuated by periods of lake-level rises and widespread lacustrine shale [40]. The main fault, known as the Lokichar Fault, has a relatively low angle with planar sections, despite a dip that varies considerably (from $12^{\circ}$ to $60^{\circ}$ ) along strike [41]. The J1 Oilfield covers an approximate area of $1100 \mathrm{~km}^{2}$ with $14.04 \times 10^{8} \mathrm{Sm}^{3}$ of oil originally in place (OOIP). 


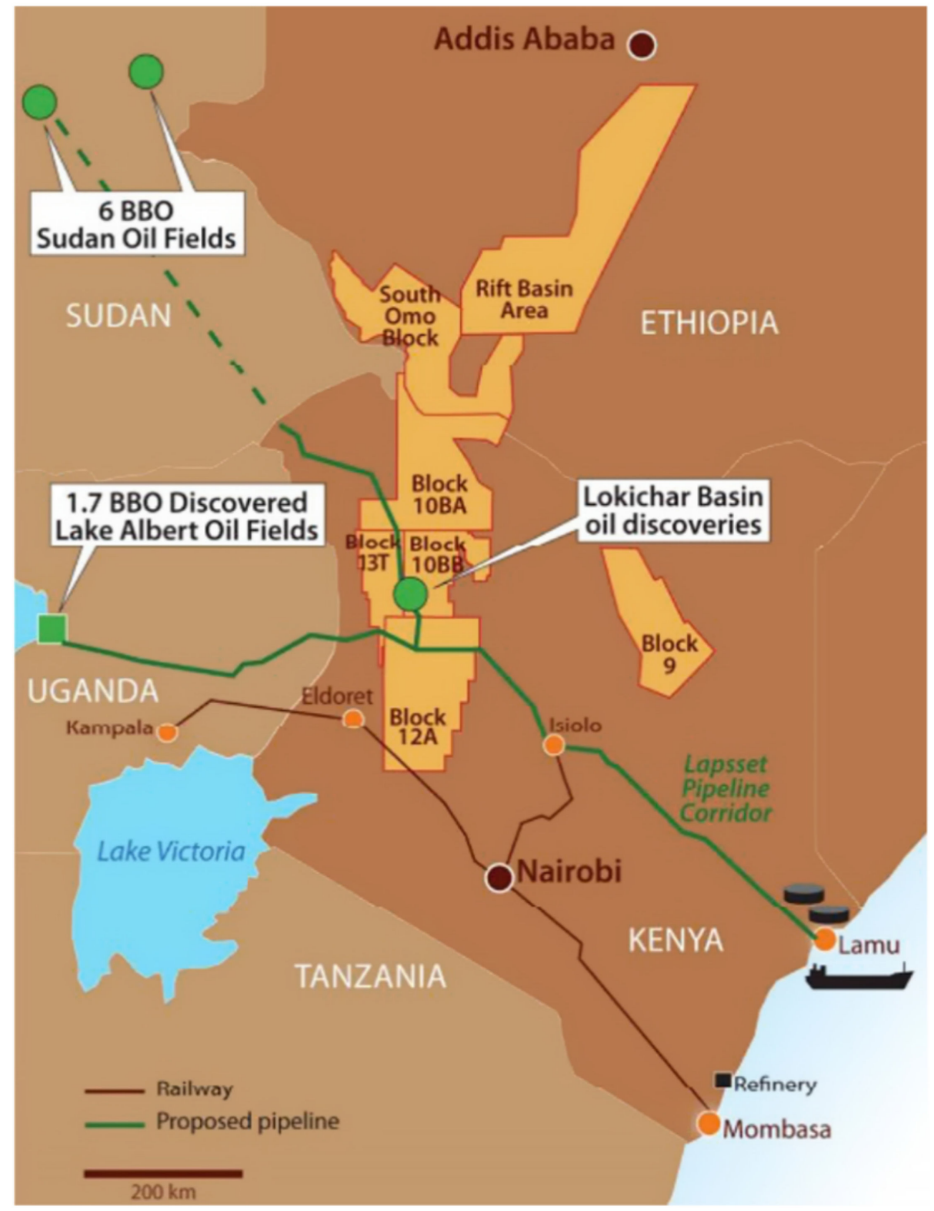

Figure 2. Location of the Lokichar Basin (green circle) and surrounding areas where oil has been discovered (Block 10BA, Block 13T, Block 10BB, Block 12A, and Block 9). The green straight line from Lamu port to Lake Albert represents a proposed pipeline route for transporting crude oil. Black circles represent major surrounding cities.

\subsection{Static Reservoir Modeling}

Figure 3 shows the lithology sequences of the studied field. The static reservoir model was prepared using Schlumberger's Petrel software suite, 2015 version, on the basis of the latest processed seismic data from the J1 field. Geological modeling is highly important because it (1) provides a robust means of field evaluation and (2) enables volumetric calculations that provide the best technical case for determining static stock tank oil originally in place (STOOIP) and gas initially in place (GIIP) values [42]. The inputs for reservoir simulation were supported by history-matching the test well to the potential drilling targets and their associated profiles. A geological reservoir model was generated on the basis of (1) the depositional environment, (2) lithology and continuity, (3) reservoir sand thickness, and (4) structural geometry. First, the formation outcrops were examined to characterize the depositional environment. The outcrops were analogous to well-documented Oligocene-Miocene outcrops from the Ebro River Basin in Spain [43,44]. Therefore, the outcrops were modeled as a sequence of middle Miocene fluvial-lacustrine deposits. The reservoir interval was regionally split into 7 reservoir zones (B01, B27, B15, $\mathrm{B} 17, \mathrm{~B} 25, \mathrm{~B} 27$, and B30) on the basis of lake-level fluctuations. To improve reservoir layering in the model, we introduced two additional surfaces that split B30 and B27 into upper and lower members (i.e., B30L and B30U, and B27L and B27U, respectively). 

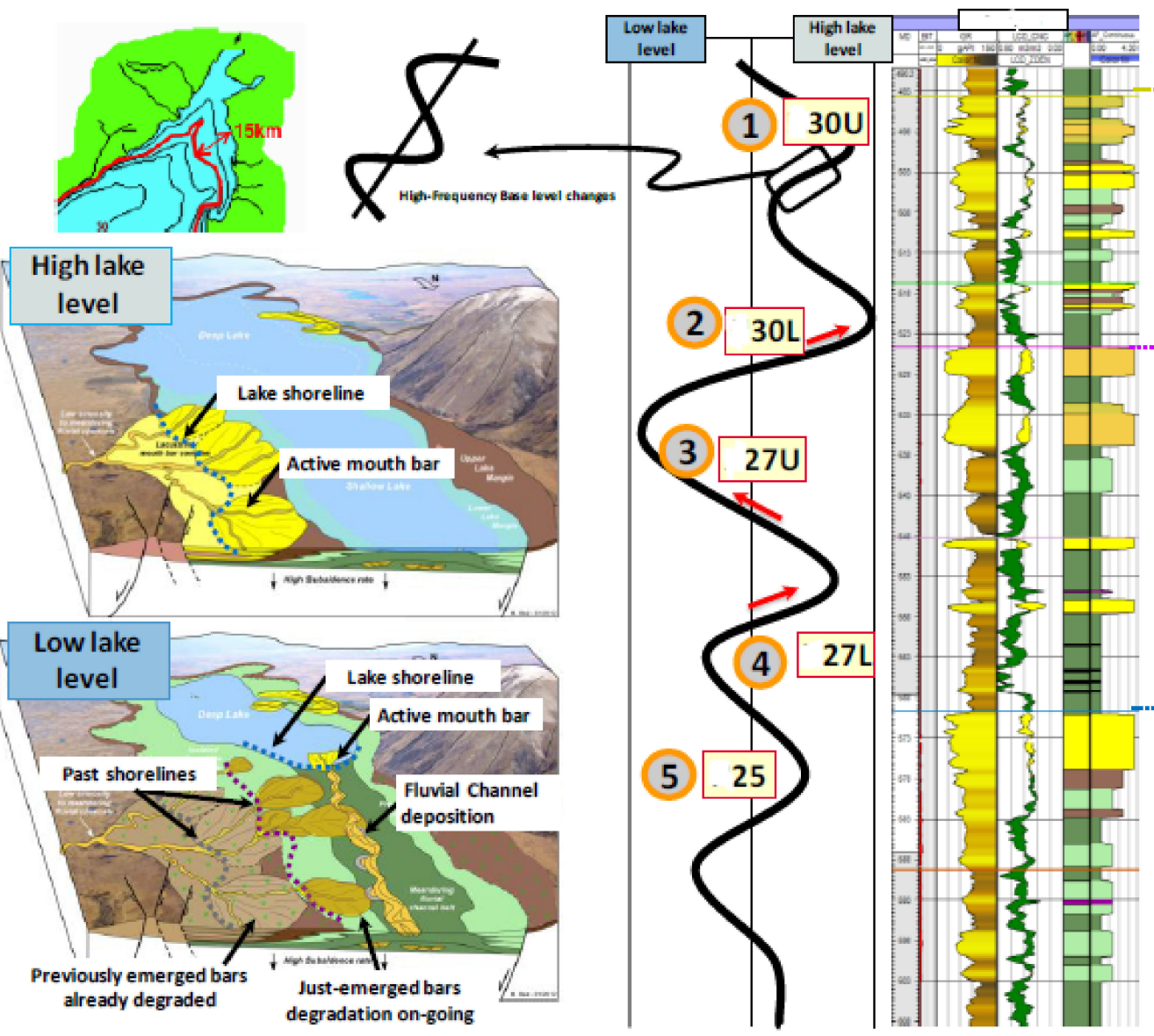

$30 \mathrm{U}$

Phie $23 \%$

$\mathrm{NtG}^{*} 38 \%$

Kh 5-15D

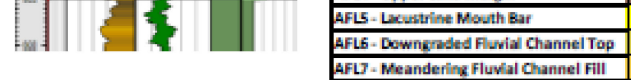

Figure 3. Lithology sequences of the studied field.

The base of B30L corresponds to a major lacustrine flooding event interpreted as a vertical seal between the B30 and B27-B15 intervals. A barrier also prevents pressure communication within B30U, which isolates the uppermost reservoir layers from the main sand bodies. The B17 layer is predominantly a shale interval, and pressure data suggest that the B15 layer is connected to B25 under static conditions. Table 1 lists the 6 rock types defined in the model on the basis of their permeability distributions and respective fluid saturation. The relative permeability curves used during the simulation for the rock types are shown in Figure 4.

Table 1. Rock types defined in the model and their corresponding horizontal permeability- $k_{H}$ $\left(\mathrm{m}^{2}\right)$ distributions.

\begin{tabular}{cc}
\hline Rock Type (Based on Permeability Distribution) & Permeability Range \\
\hline Type (I) & $k_{H}<1.1 \times 10^{-11} \mathrm{~m}^{2}$ \\
Type (II) & $1.1 \times 10^{-11} \leq k_{H}<2.5 \times 10^{-10} \mathrm{~m}^{2}$ \\
Type (III) & $2.5 \times 10^{-10} \leq k_{H}<1.0 \times 10^{-9} \mathrm{~m}^{2}$ \\
Type (IV) & $1.0 \times 10^{-9} \leq k_{H}<4.0 \times 10^{-9} \mathrm{~m}^{2}$ \\
Type (V) & $4.0 \times 10^{-9} \leq k_{H}<1.5 \times 10^{-8} \mathrm{~m}^{2}$ \\
Type (VI) & $k_{H} \geq 1.5 \times 10^{-8} \mathrm{~m}^{2}$ \\
\hline
\end{tabular}




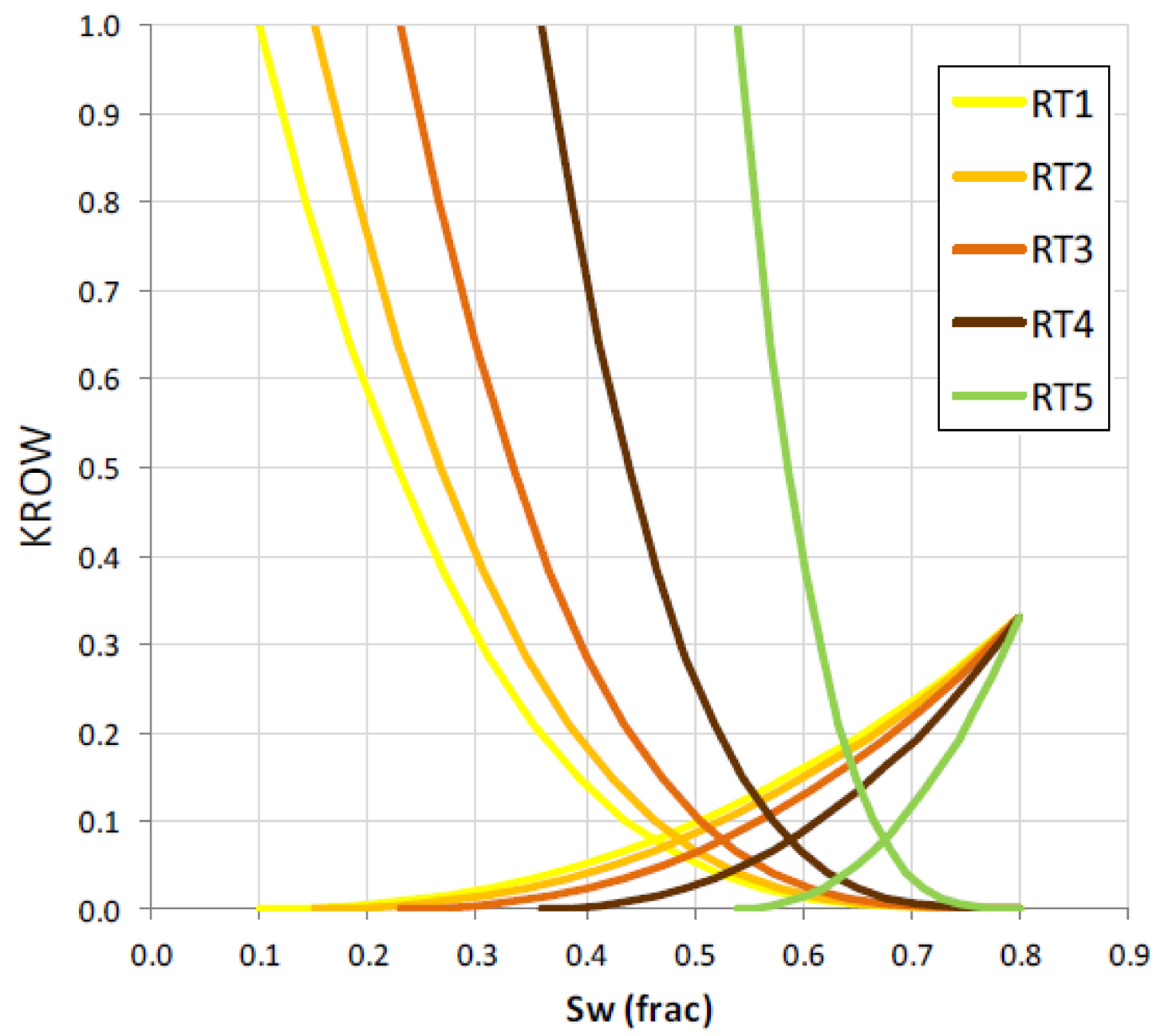

Figure 4. The relative permeability function for each rock type.

The static geological model contained $305 \times 390 \times 173=3,144,960$ cells with a cell size of $50 \times 50 \times 2 \mathrm{~m}$ and a total of 112 layers, each with an average thickness of $1.7 \mathrm{~m}$. Hydrocarbons in place (split per interval: 33\% in B30, 55\% in B27, and 12\% in B25) were calculated using the different properties populated in the main J1 model (PhieNet, NTG, and Sw).

\subsection{Contact Sets: Oil-Water and Gas-Oil}

Oil-water contacts (OWCs) were obtained using the following two methods. First, pressure data were used to develop pressure versus depth plots for each reservoir unit (B27U and B27L), focusing on the point of intersection with the water zones (B17 and B15). Second, well-log analyses were used to identify lithologies on the basis of observations of density neutron separation and gamma-ray response, along with a review of core resistivity and sand-body distribution. Final and fine OWC sets (Table 2) were derived using the "oil down to" (ODT) concept, that is, the depth of the lowest known hydrocarbons $[12,45,46]$. The gas-oil contact (GOC) sets applied values obtained directly from the seismic amplitude analysis. Tables 3 and 4 present the OWCs and GOCs, respectively, for reservoir B27. No gas was found in B27U in the J1-1 block. 
Table 2. Depths of water-oil contact (m) for the J1 Oil Field.

\begin{tabular}{cccccc}
\hline Block & B30U & B30L & B27U & B27L & B25 \\
\hline J1 SE-1 & -437.52 & -449 & -487 & -487 & -509 \\
\hline J1 SW-2 & -532.04 & -543 & -547 & -547 & Water \\
\hline J1 C-3 & -485.00 & -485 & -543 & -543 & -570 \\
\hline J1 N-4 & -581.05 & -590 & -636 & -636 & -647 \\
\hline
\end{tabular}

Table 3. Depths of water-oil contact (m) for the B27 reservoir.

\begin{tabular}{ccc}
\hline Block & B27U & B27L \\
\hline J1 SE-1 & -487 & -487 \\
\hline J1 SW-2 & -547 & -547 \\
\hline J1 C-3 & -543 & -543 \\
\hline J1 N-4 & -636 & -636 \\
\hline
\end{tabular}

Table 4. Depths of gas-oil contact (m) for the B27 reservoir.

\begin{tabular}{ccl}
\hline Block & B30U & B27U \\
\hline J1 SE-1 & -420 & N/A \\
\hline J1 C-3 & -440 & -495 \\
\hline
\end{tabular}

\subsection{Dynamic Model Development}

The geological model was transferred to the Eclipse black oil simulator without upscaling. The simulation model was initialized with 17 active equilibrium and 10 pressurevolume-temperature (PVT) regions, each listed with its own OWC and GOC. PVT tables and pressure initialization (Table 5) were defined on the basis of the reservoir characterization instrument (RCI)/module formation tester dynamic tool (MDT) pressure and quad measurements, which are in turn based on permeability distributions. Figure 5 shows the porosity and permeability distributions of rock types in reservoir. Uchida et al. (2015) and Ashqar et al. (2016) discussed the factors that should be considered when classifying rock type for reservoir modeling and evaluation $[47,48]$. It is noted that when classifying different rock types, facies, porosity, and permeability are all considered. In this work, permeability is the main factor in the consideration because permeability controls the flow of the fluid in reservoir. In fact, facies and porosity are related to permeability. Usually, low porosity is corresponding to low permeability and high porosity is related to high permeability. The facies can be represented by their typical porosity-permeability. Therefore, facies and porosity are considered in the rock type classification implicitly. Rock type (VI) has the highest permeability, whereas rock type (I) has the lowest permeability (Table 2). Therefore, rock type (I) was considered to be predominantly shale saturated with water and was deactivated in the dynamic model. The average cell size was approximately $50 \times 50 \times 2 \mathrm{~m}$, with the vertical permeability derived from the static model calculated using values of $k_{V} / k_{H}$ for each facies association (AFL). Minimum and maximum pressures of 10 and 60 bars, respectively, and a reservoir temperature and reference pressure of $54.5^{\circ} \mathrm{C}$ and 51.3 bars, respectively, were used. The dynamic model contained only 303,957 active cells, mainly as a result of the perimeter effect, with an OOIP of $30.2 \times 10^{6} \mathrm{Sm}^{3}$ (Table 6). As each block and reservoir tends to be statically disconnected, in Figure 6, regions with the highest oil concentrations are indicated in red. The change in color toward blue indicates an increase in water saturation. During the modeling process, the B27 reservoir was divided into B27U and B27L; Figure 7a,b shows fluid saturation in the lower B27 reservoir, and Figure $7 \mathrm{c}, \mathrm{d}$ shows the distributions in the upper sections of the reservoirs. 
Table 5. Petrophysical and fluid properties of the reservoir rock.

\begin{tabular}{cc}
\hline Rock Properties & Fluid Properties \\
\hline Grid size $(\mathrm{m}), 50 \times 50$ & Water saturation $(\mathrm{Sw}$; fraction) 0.2 \\
Porosity $(\%), 28$ & Initial oil saturation $(\mathrm{Soi}$; fraction) 0.8 \\
Perm. $V /$ Perm. $H\left(k_{V} / k_{H}\right), 0.1$ & Reservoir fluid density $\left(\mathrm{kg} / \mathrm{m}^{3}\right), 855$ \\
Initial reservoir pressure $(\mathrm{MPa}), 5.1$ & Fluid viscosity $\left(\mathrm{N} \cdot \mathrm{s} / \mathrm{m}^{2}\right), 0.0167$ \\
Formation depth $(\mathrm{m}), 800$ & Oil gravity $\left({ }^{\circ} \mathrm{API}\right), 25.3$ \\
Formation volume factor $(\mathrm{FVF})\left(\mathrm{m}^{3} / \mathrm{Sm}^{3}\right), 1.071$ & \\
\hline
\end{tabular}

\section{Phi-K by Rock Type}

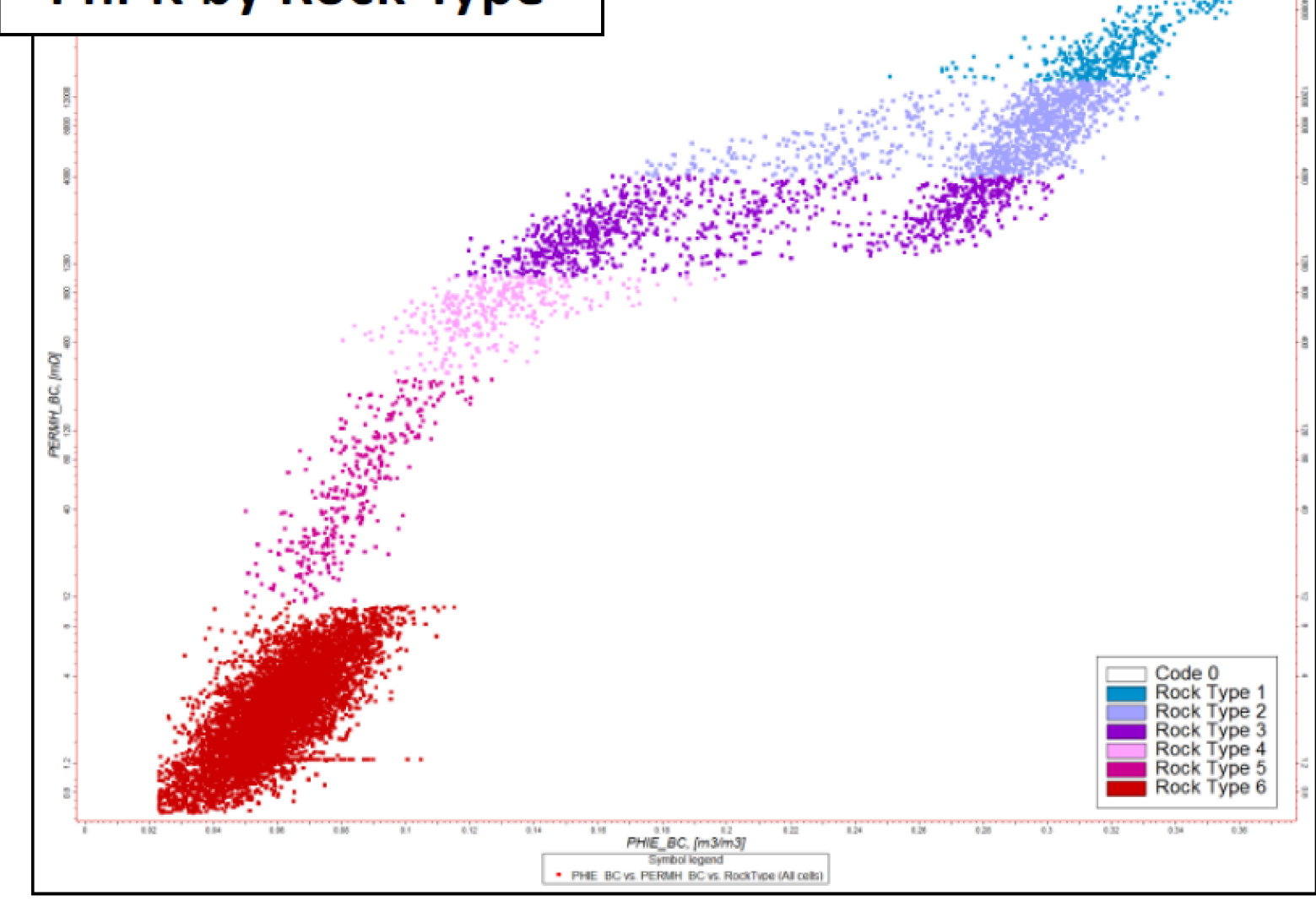

Figure 5. The distribution of porosity and permeability of different rock types in the reservoir.

Table 6. Recoverable volumes in the B14U and B14L zones.

\begin{tabular}{cccc}
\hline \multirow{2}{*}{ Reservoir } & Block & $\begin{array}{c}\text { OOIP } \\
\left(\mathbf{1 0}^{\mathbf{6}} \mathbf{S m}^{\mathbf{3}}\right)\end{array}$ & Recoverable Oil (106 $\left.\mathbf{S m}^{\mathbf{3}}\right)$ \\
\hline \multirow{3}{*}{ B14U } & J1 C-3 & 10.4 & 2 \\
\cline { 2 - 4 } & J1 SW-2 & 4.2 & 1 \\
\cline { 2 - 4 } & J1 SE-1 & 51.8 & 8 \\
\hline \multirow{2}{*}{ B14L } & J1 N-4 & 11.9 & 2 \\
\cline { 2 - 4 } & J1 C-3 & 11.5 & 2 \\
\cline { 2 - 4 } & J1 SW-2 & 7.1 & 1 \\
\cline { 2 - 4 } & J1 SE-1 & 81.2 & 13 \\
\hline & J1 N-4 & 12 & 30 \\
\hline
\end{tabular}




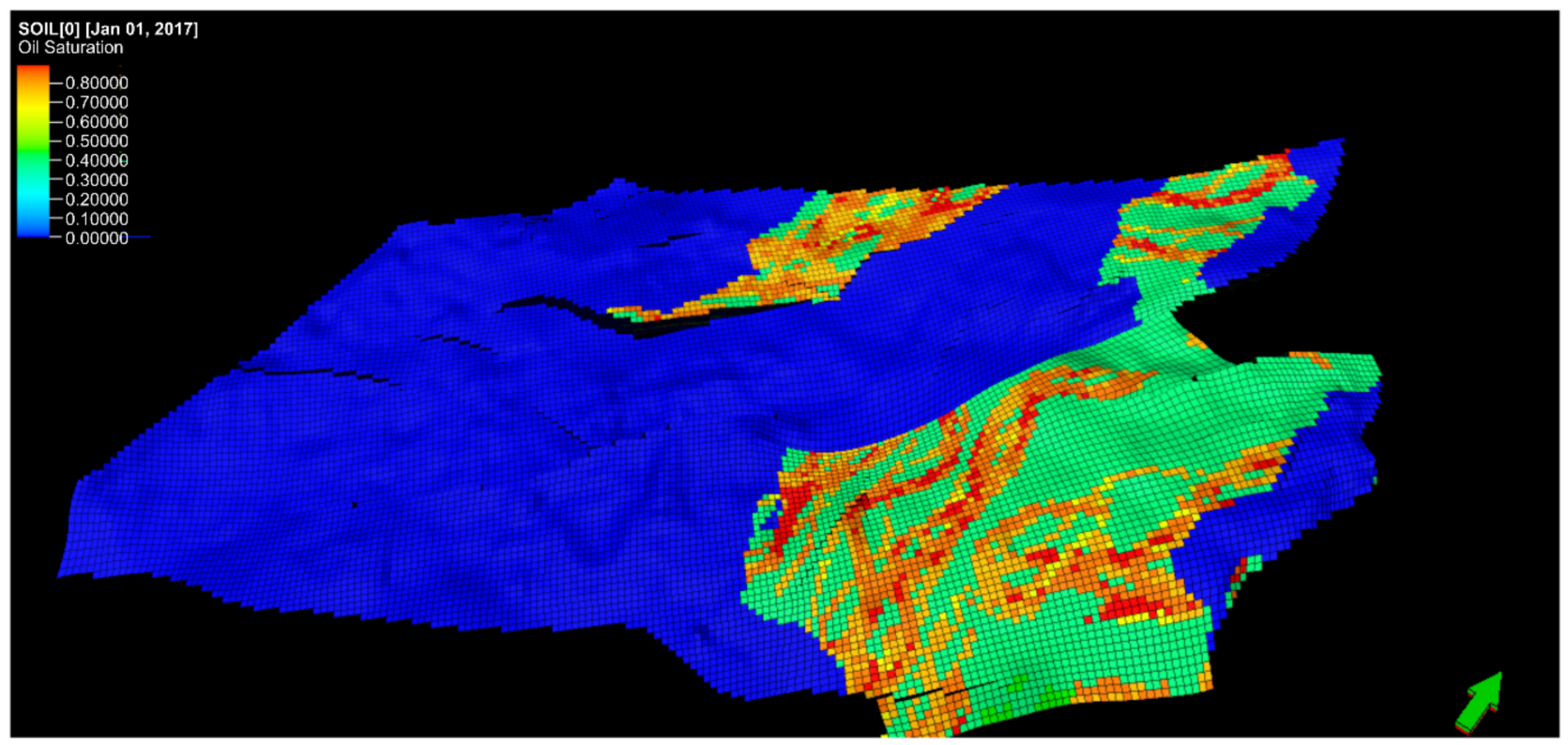

Figure 6. Oil saturation (fraction) in the B27 reservoir in the J1 Oilfield. The change in color toward red indicates increasing oil concentrations, while the change in color toward blue indicates increasing water concentrations.

\subsection{Mathematical Fluid Flow Models}

Mass and momentum conservation laws govern the dynamics of fluid flow transport and its interaction with porous media. Buckley and Leverett (1942) presented a fractional flow equation for two-phase flow in homogenous reservoirs with communicating layers. However, our study focuses on flow in heterogeneous reservoirs [49].

\subsection{Well Design}

Figure 8 shows the trajectory of the designed wells with different radii of curvature, and Figure 9 shows the flood design and well placement, with the producer wells located on the basis of the identification of grid blocks with a high residual oil saturation, high porosity, and good reservoir quality. Injector wells were placed in regions with appropriate connectivity and permeability. The average porosity was $28 \%$, and the horizontal to vertical permeability ratio $\left(k_{V} / k_{H}\right)$ was 0.1 for the base case $[50,51]$. The $k_{V} / k_{H}$ ratio is an important fluid flow factor when creating models consistent with field performance. When the ratio is greater than 1, more flow occurs in the vertical direction compared with that in the horizontal direction; when the ratio is less than 0.1 , there are more restrictions on fluid flow in the vertical direction. Moreover, as discussed by Kasap (2001), an empirically derived $k_{V} / k_{H}$ ratio of 0.1 is commonly recommended in the oil industry to account for fluid flow movement [50]. Regions with proper facies distribution, porosity, and permeability were selected for perforation. Perforation regions for the injectors were always placed deeper than those for the producer wells in the same location to allow for the upward vertical flow of oil. To select the best development scenario, we compared four flooding patterns: (1) vertical injectors and vertical producers, (2) vertical injectors and highly deviated producers, (3) vertical injectors and multilateral producers, (4) vertical injectors and horizontal producers. Vertical injectors were applied for all patterns because of their cost-effectiveness in shallow reservoirs. Vertical injector can also delay the water breakthrough and enhance oil recovery. For all the cases, the ratio of producer to injector was almost 1:1. For the second case, the recommended highly deviated well arrangement included 40 producers and 38 vertical injectors in the B27U and B27L reservoir zones. These B27 reservoir panels were selected because they contained higher volumes of oil than the B30 reservoir zone. The laterals were placed at $68^{\circ}$ with a maximum distance of $60.96 \mathrm{~m}$ from the vertical section and with a short radius of 5-10 $\mathrm{m}$ from each section to ensure 
larger distances within high-porosity zones [22,52]. For third case, two to three laterals were planned to maximize the horizontal and vertical sweep efficiency for waterflooding using this design. Well indices were calculated on the basis of Peaceman's equation (Equation (2)) for wells characterized by perpendicular penetration through the center of rectangular grid blocks. For fourth case, medium-to-short radius horizontal wells (Figure 8) were used.
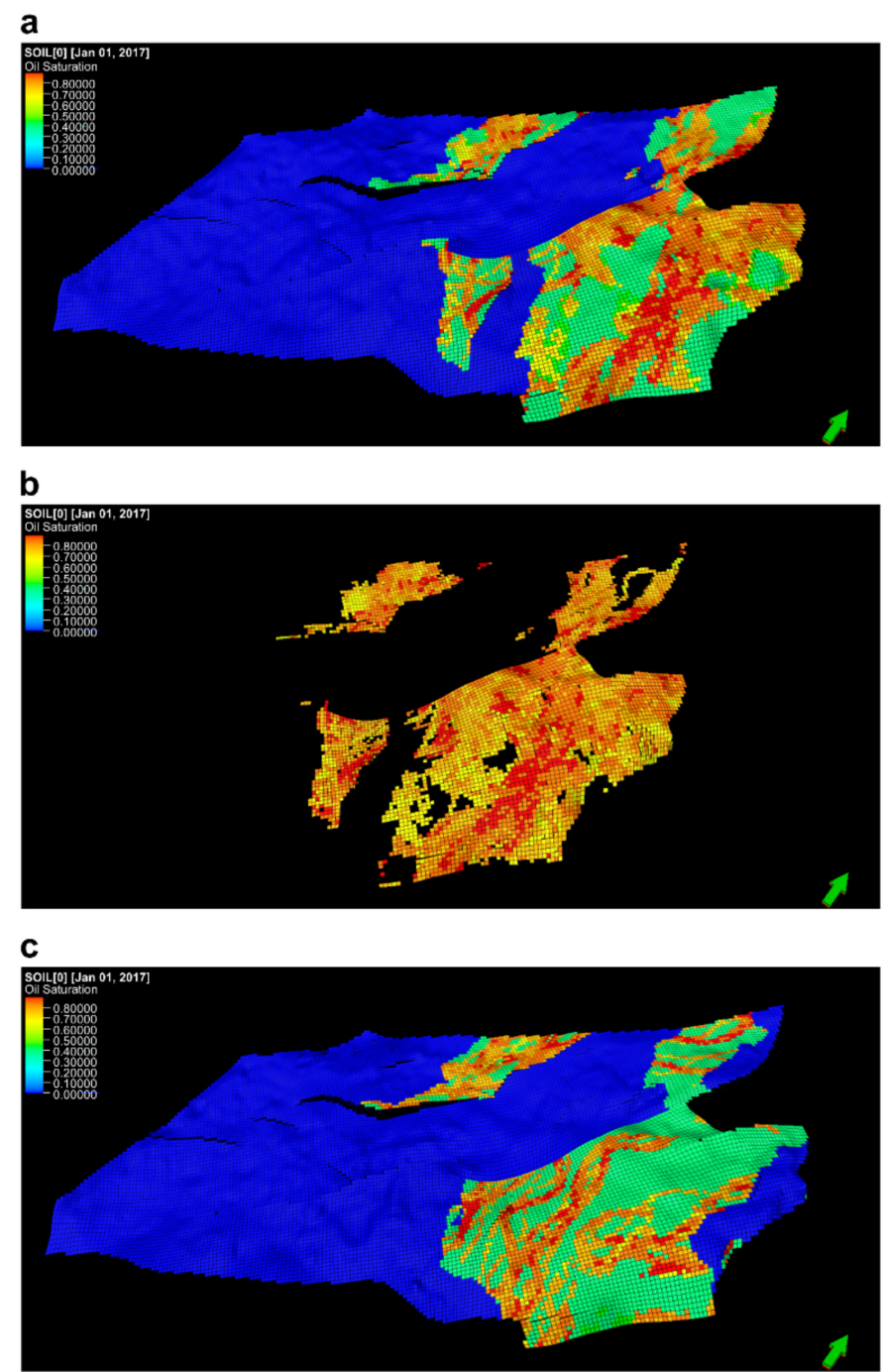

d

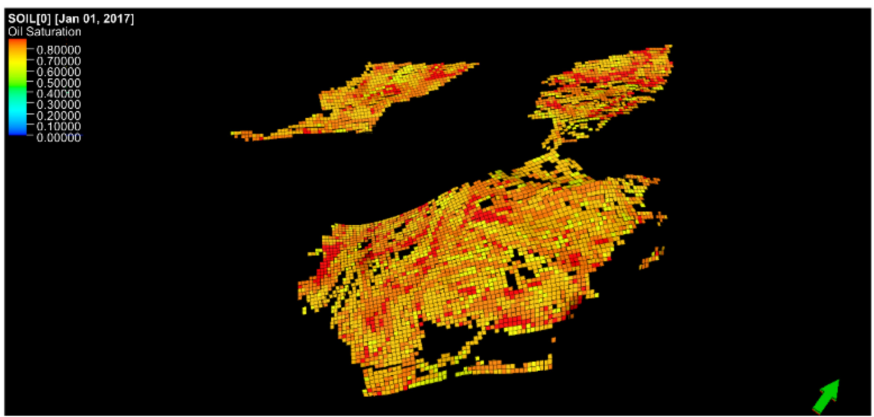

Figure 7. Hydrocarbon distribution and oil saturation $\left(\mathrm{Sm}^{3}\right)$ in the B27 reservoirs: (a) hydrocarbon saturation maps for the B27L reservoir zone; (b) highest oil saturation distribution map for the B27L reservoir zone; (c) hydrocarbon fluid saturation map for the B27U reservoir zone; (d) highest oil saturation map for the B27U reservoir zone. Change in color towards red indicates an increasing oil concentration; red-colored areas have the highest concentration of oil. On the contrary, change in color towards blue indicates an increase in the water concentrations. 


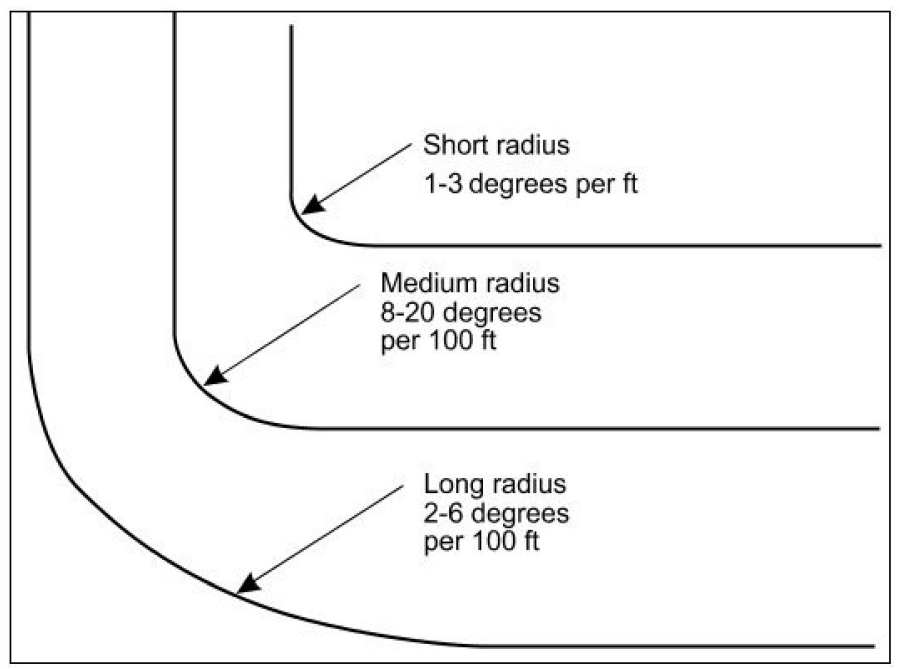

Figure 8. The classification of different radii of the curvature section of deviated wells.

Vertical wells were completed throughout the entire formation thickness and their flow indices were calculated to be $\approx 0.1$. The layer flow indices were calculated as follows:

$$
P I D_{V K}=\left(\frac{0.00708 k h}{\operatorname{Ln}\left(r_{e} / r_{w}\right)+S}\right),
$$

where $r_{e}$ is the equivalent gridlock radius $(\mathrm{ft}), r_{w}$ is the wellbore radius $(\mathrm{ft}), h$ is the $\mathrm{Z}$ dimension (layer thickness) of the block (ft), $k$ is the mean $\mathrm{X}-\mathrm{Y}$ permeability $(\mathrm{mD})$, and $S$ is the layer skin factor. These PID values apply to vertical wellbores; PID values for horizontal wellbores were calculated as follows:

$$
\begin{gathered}
\operatorname{PID}_{H K}=\frac{0.00708 K_{H^{h}}}{\operatorname{Ln}\left(\frac{a+\sqrt{a^{2-(L / 2)^{2}}}}{(L / 2)}\right)+\left(\frac{L_{a n i} h}{L} \times \ln \frac{I_{a n i h}}{\left.r_{w\left(I_{a n i+1}\right)}\right)}+S\right.} \\
I_{a h_{i}}=\sqrt{\frac{k_{H}}{k_{v}}},
\end{gathered}
$$

and

$$
a=\left(\frac{L}{2}\right) \times \sqrt{0.5+\left[0.25+\left(\frac{r_{e H}}{L / 2}\right)^{4}\right]^{0.5}},
$$

where $k_{H}$ is the horizontal permeability $(\mathrm{mD}), h$ is the Z-dimension (layer thickness) of the block (ft), $L$ is the length of the horizontal section of the well $(\mathrm{ft}), k_{v}$ is the vertical permeability $(\mathrm{mD}), r_{e H}$ is the drainage radius of the horizontal wellbore $(\mathrm{ft}), I_{a n i}$ is the index of horizontal-to-vertical permeability anisotropy, and $a$ is the large half-axis (a) of the drainage ellipse formed by a horizontal wellbore. The radius, $r_{e}$, was calculated using Peaceman's formula [53]. Multilateral wells have different configurations; here, we considered dual laterals because of their accelerated rate of recovery and reduced water production [54]. 

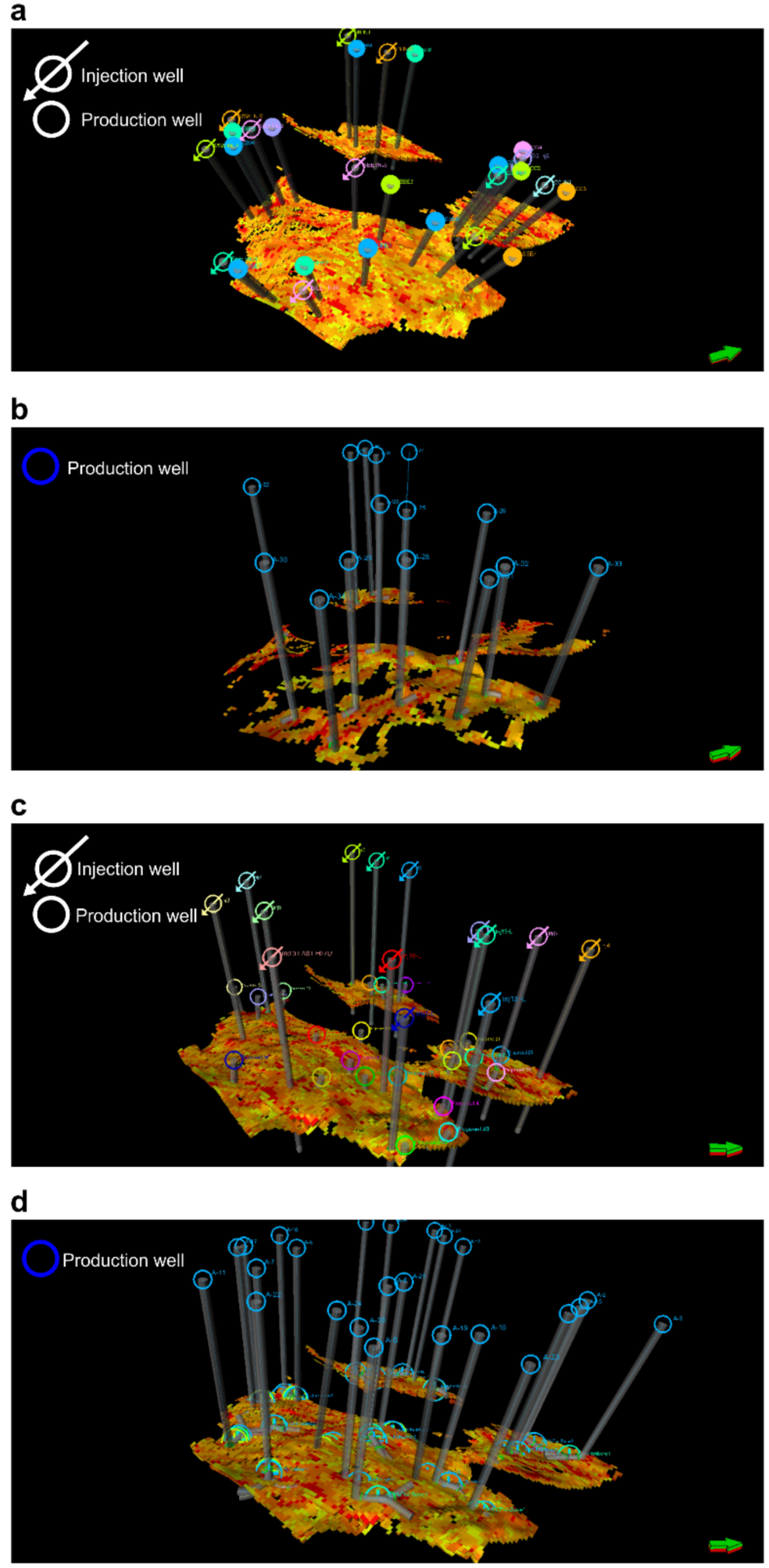

Figure 9. Planned well design and placement. (a) Vertical well placement, (b) horizontal well placement, (c) highly deviated well placement, and (d) multilateral well placement.

\subsection{Development Strategy}

We observed that the minimum horizontal stress was $0.13 \mathrm{bars} / \mathrm{m}$ below the vertical stress $(0.178 \mathrm{bars} / \mathrm{m})$. Thus, the injection pressure $(1.89 \mathrm{psi} / \mathrm{m})$ was used to prevent any risk of re-opening of pre-existing faults, which would have damaged the cap-rock integrity. Producer wells were controlled with a minimum bottom hole pressure of $145 \mathrm{psi}$ for all 
well scenarios, while the well rate production control was set at a maximum liquid rate of 5000 STB/D. The group production control target was 20,000 STB/D. The water-cut for each well was $95 \%$, considering the worst perforation. The waterflood development strategy was designed for a period of 25 years. In the baseline scenario, 16 highly deviated producer wells were used in the B27U reservoir and 24 highly deviated producer wells were used in the B27L reservoir. The number of vertical water injection wells used in the two scenarios were 16 and 24, respectively. Table 7 lists the number of wells used in the design for the development of each reservoir block.

Table 7. Number of wells planned in each reservoir block.

\begin{tabular}{|c|c|c|c|}
\hline Well Type & Reservoir Zone & Producers & Injectors \\
\hline \multirow{2}{*}{ Vertical } & B27U & 15 & 15 \\
\hline & B27L & 18 & 16 \\
\hline \multirow{2}{*}{ Horizontal } & B27U & 24 & 23 \\
\hline & B27L & 14 & 14 \\
\hline \multirow{2}{*}{ Highly deviated } & B27U & 16 & 16 \\
\hline & B27L & 24 & 22 \\
\hline \multirow{2}{*}{ Multilateral } & B27U & 10 & 9 \\
\hline & B27L & 14 & 14 \\
\hline
\end{tabular}

\section{Results and Discussion}

The results of the simulations are presented in Table 8 and Figure 10. The production performances of different well configurations were evaluated on the basis of cumulative oil production. The horizontal wells outperformed all the other well types in terms of cumulative oil recovery. This can be attributed to the single horizontal lateral section, which penetrates more pay zones, thereby creating a wide contact surface area for drainage $[55,56]$. Highly deviated wells have a similar lateral extension, but their sections are slanted. This affects oil recovery from shallow reservoirs (which are also composed of vertical non-communicating layers), resulting in the lowest recovery among the four well types (Figure 10d). In contrast, multilateral wells should have the highest recovery because of their lateral branching structure $[57,58]$. However, these wells only exhibited the highest production during the first three years of operation before sharply decreasing to the same production rates as those of the vertical wells. This decline can be attributed to the following two factors: (1) slanting laterals reduced the contribution of vertical permeability to productivity; (2) the additional contact area between the wellbore and reservoir may have led to fluid flow resistance in shallow pay zones. However, this can be resolved with inflow control valves (ICV) in smart well configurations. The production of multilateral wells was approximately 5\% higher than that of highly deviated wells. The small difference was due to the substantial cumulative exposure of laterals within the entire reservoir relative to the single sections of the highly deviated wells [57]. Nevertheless, this effect was not pronounced because the reservoir is relatively shallow. Here, the negative effect of reduced productivity due to slanting overshadowed the positive effect of increased reservoir thickness. Well spacing significantly affects the key indicators of the field development such as the rate of liquid and oil recovery from the reservoir, completeness of oil sweep out from the producing formation, the hydrocarbons' ultimate recovery factor, reservoir producing life, and a number of other indicators of development. 
Table 8. Production performance of each well type by property.

\begin{tabular}{|c|c|c|c|c|}
\hline \multirow[t]{2}{*}{ Well Type } & \multirow[t]{2}{*}{ Property } & \multicolumn{3}{|c|}{ Production } \\
\hline & & 5 years & 15 years & 25 years \\
\hline \multirow{5}{*}{ Vertical well } & Water cut & 0.79 & 0.89 & 0.93 \\
\hline & Gas production rate $\left(\mathrm{Sm}^{3} / \mathrm{d}\right)$ & 804.764 & 213.257 & 132.483 \\
\hline & Oil production rate $\left(\mathrm{Sm}^{3} / \mathrm{d}\right)$ & 1531.5 & 432.17 & 232.73 \\
\hline & Cumulative oil production (Sm) & $5.29 \times 10^{6}$ & $8.3838 \times 10^{6}$ & $9.57 \times 10^{6}$ \\
\hline & Recovery efficiency (\%) & 17.4 & 27.0 & 31.0 \\
\hline \multirow{5}{*}{ Horizontal well } & Water cut & 0.89 & 0.91 & 0.92 \\
\hline & Gas production rate $\left(\mathrm{Sm}^{3} / \mathrm{d}\right)$ & 1019.519 & $23,336.055$ & 2533.6 \\
\hline & Oil production rate $\left(\mathrm{Sm}^{3} / \mathrm{d}\right)$ & 1850.4 & 417.7 & 128.37 \\
\hline & Cumulative oil production (Sm) & $5.71 \times 10^{6}$ & $9.27 \times 10^{6}$ & $1.01 \times 10^{7}$ \\
\hline & Recovery efficiency (\%) & 19.0 & 31.0 & 33.0 \\
\hline \multirow{5}{*}{ Multilateral well } & Water cut & 0.86 & 0.92 & 0.94 \\
\hline & Gas production rate $\left(\mathrm{Sm}^{3} / \mathrm{d}\right)$ & 1036.736 & 218.209 & 107.575 \\
\hline & Oil production rate $\left(\mathrm{Sm}^{3} / \mathrm{d}\right)$ & 1525.8 & 389.64 & 1920.3 \\
\hline & Cumulative oil production (Sm) & $5.64 \times 10^{6}$ & $8.6 \times 10^{6}$ & $9.53 \times 10^{6}$ \\
\hline & Recovery efficiency (\%) & 18.6 & 28.0 & 31.0 \\
\hline \multirow{5}{*}{ Highly deviated well } & Water cut & 0.86 & 0.88 & 0.9 \\
\hline & Gas production rate $\left(\mathrm{Sm}^{3} / \mathrm{d}\right)$ & 70.1408 & 197.872 & 89.758 \\
\hline & Oil production rate $\left(\mathrm{Sm}^{3} / \mathrm{d}\right)$ & 1269.7 & 338.9 & 157.46 \\
\hline & Cumulative oil production (Sm) & $5.07 \times 10^{6}$ & $7.39 \times 10^{6}$ & $8.14 \times 10^{6}$ \\
\hline & Recovery efficiency (\%) & 16.7 & 24.0 & 26.0 \\
\hline
\end{tabular}

In addition, owing to the complex heterogeneity of the B27 reservoirs, permeability variations in the different parts of the reservoir and corresponding well locations partially affect the relatively small increase in the production rate. Overall, vertical wells performed better than highly deviated wells, identical to multilateral wells, and slightly poorer than horizontal wells (Figure 10a). The improved production in the vertical wells (as compared with the highly deviated wells) can be attributed to the reservoir structure. B27 reservoirs are shallow, creating a perforation that can be easily vertically assigned in the hydrocarbonbearing reservoir sands in different zones. This can easily increase productivity relative to the high-angle barriers in the slanted highly deviated wells. Here, J1 also has vertical pressure disconnections, which can affect the reservoir pressure and water infectivity process, particularly in unconventional wells.

\subsection{Production Plots for Each Well Type}

\subsubsection{Vertical Wells}

Figure 10a shows that, during the first 2.5 years of production, the oil production rate remained constant at $3180 \mathrm{Sm}^{3} / \mathrm{d}$, and the water production was $7809.3 \mathrm{Sm}^{3} / \mathrm{d}$, exhibiting a steady increase during this period. The water-cut also steadily increased to $72 \%$ at maximum production. Near the beginning of the third year of production, the oil rate declined sharply (by $55 \%$ ) to $1426.1 \mathrm{Sm}^{3} / \mathrm{d}$ until August 2022. Water production decreased steadily over the same period. However, the water-cut steadily increased throughout waterflooding. After 2022, we observe a steady decrease in the oil production rate, leading to a cumulative oil production of $9.6 \times 10^{6} \mathrm{Sm}^{3}$. Vertical wells drilled perpendicular to the reservoir section, which in this case is a shallow reservoir, can only sweep hydrocarbons that lie directly beneath the reservoir section. Thus, we observed a sharp decrease in production after a short period of operation. 

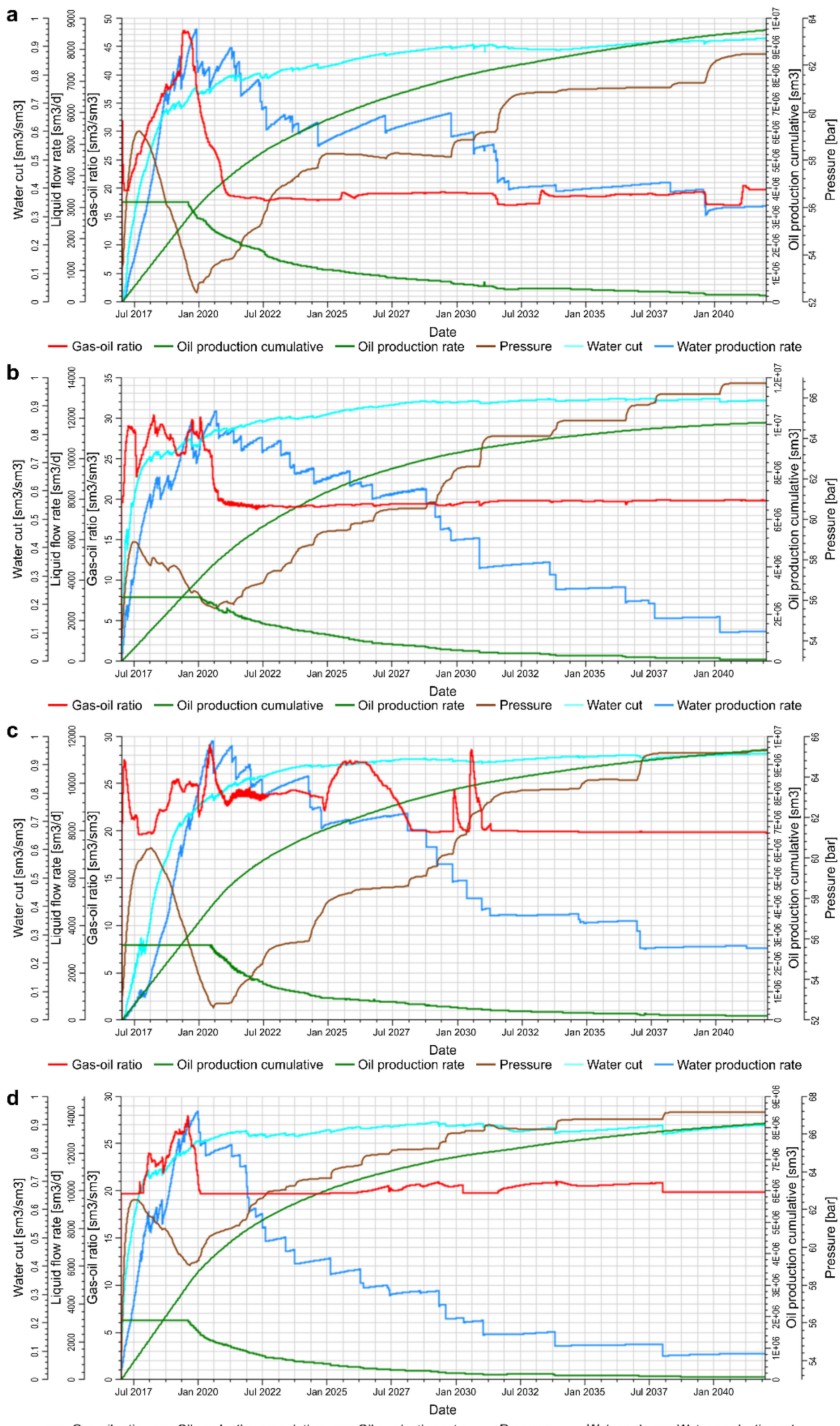

Figure 10. Trends in different properties for each well type. (a) Performance of vertical wells in the B27 reservoir, (b) production profiles of horizontal wells in the B27 reservoir, (c) performance of multilateral wells in the B27 reservoir, and (d) production profiles showing the performance of highly deviated wells in the B27 reservoir. The pressure considered is the reservoir pressure. 


\subsubsection{Horizontal Wells}

Horizontal wells dug at an angle of at least $80^{\circ}$ to a vertical wellbore are known to reach deeper pay zones and have a wide contact surface for oil drainage. Figure 10b shows that the initial oil production rate of $3180 \mathrm{Sm}^{3} / \mathrm{d}$ remained constant for the first three years of production, which represents nearly six more years of production compared with the vertical wells. The water production rate increased steadily from the first year of production, reached a maximum of $11,676 \mathrm{Sm}^{3} / \mathrm{d}$, and then sharply decreased to $9768.8 \mathrm{Sm}^{3} / \mathrm{d}$ in the final month of the first three years of production. The water-cut was as high as $78 \%$ throughout the extended period of production. The oil production rate decreased steadily until the end of waterflooding, yielding a cumulative oil production of $1.012 \times 10^{7} \mathrm{Sm}^{3}$. Cumulative oil production in the horizontal wells was $5.21 \%$ higher than that in the vertical wells.

\subsubsection{Multilateral Wells}

The oil production rate of the multilateral wells was maintained at a constant rate of $3180 \mathrm{Sm}^{3} / \mathrm{d}$ for a slightly longer period (3.5 years) compared with that for the other well types before sharply decreasing (by 66\%) to $1060 \mathrm{Sm}^{3} / \mathrm{d}$ between 2024 and 2025 and then continuing to decrease at a steady rate for the entire flood period. In contrast, water production in the multilateral wells was higher and increased more rapidly than in the other well types, reaching a maximum production of $11,740 \mathrm{Sm}^{3} / \mathrm{d}$ before beginning to decline (Figure 10c). This trend reflects the numerous laterals draining different zones at the same time, leading to high cumulative water production. Similar to all other well orientations, the water-cut in the multilateral wells also steadily increased, reaching $78 \%$ at maximum oil production. Multilateral wells drilled with more than one lateral in the reservoir section were expected to produce higher volumes, but this was not found to be the case. The cumulative oil produced was $9.54 \times 10^{6} \mathrm{Sm}^{3}$, which is similar to that produced by the vertical wells, but less oil than any other well type, including that produced by the horizontal wells.

\subsubsection{Highly Deviated Wells}

Unlike the horizontal wells in which we observed a repetitive fluctuation in water production rates together with a sharp decrease in oil production during the first three years, water production in the highly deviated wells (normally drilled at an angle of $78^{\circ}$ and with a maximum angle of $81^{\circ}$ ) increased steadily from the first day of production. During this period, there was no significant decrease until production reached a maximum of $12,500 \mathrm{Sm}^{3} / \mathrm{d}$. At the same time, an oil production rate of $2812.4 \mathrm{Sm}^{3} / \mathrm{d}$ was maintained during the first 2.5 years of production (similar to the vertical wells but not the horizontal wells), before steadily decreasing until the end of the flood (Figure 10d). During the subsequent three years, oil production was maintained at $3180 \mathrm{Sm}^{3} / \mathrm{d}$. The production rate then sharply decreased (by $62 \%$ ) to $1212.4 \mathrm{Sm}^{3} / \mathrm{d}$ in August 2022. At this point, we observed a consistently decreasing trend in production until the end of the flood, which is similar to the other well types. The water-cut in the highly deviated wells increased steadily over time and reached $80 \%$ at maximum oil production. The cumulative oil production was $8.15 \times 10^{6} \mathrm{Sm}^{3} / \mathrm{d}$, which indicates that production in the highly deviated wells was $15 \%$ and $19 \%$ lower than those in the vertical and horizontal wells, respectively.

\subsection{Property Production Profiles for Each Well Type}

\subsubsection{Field Oil Production Rate}

As shown in Figure 11a, for reservoir B27, multilateral wells maintained the highest production rate followed by the horizontal wells. This better performance was a result of the horizontal and multilateral wells penetrating more of the reservoir than the vertical and highly deviated wells. However, the production of the multilateral wells declined to below that of the horizontal wells during the course of production. The additional contact area between the wellbore and reservoir reduced the resistance to fluid flow. Variations in 
permeability in different parts of the reservoir and corresponding well locations partially explain the relatively small increase in production rate.
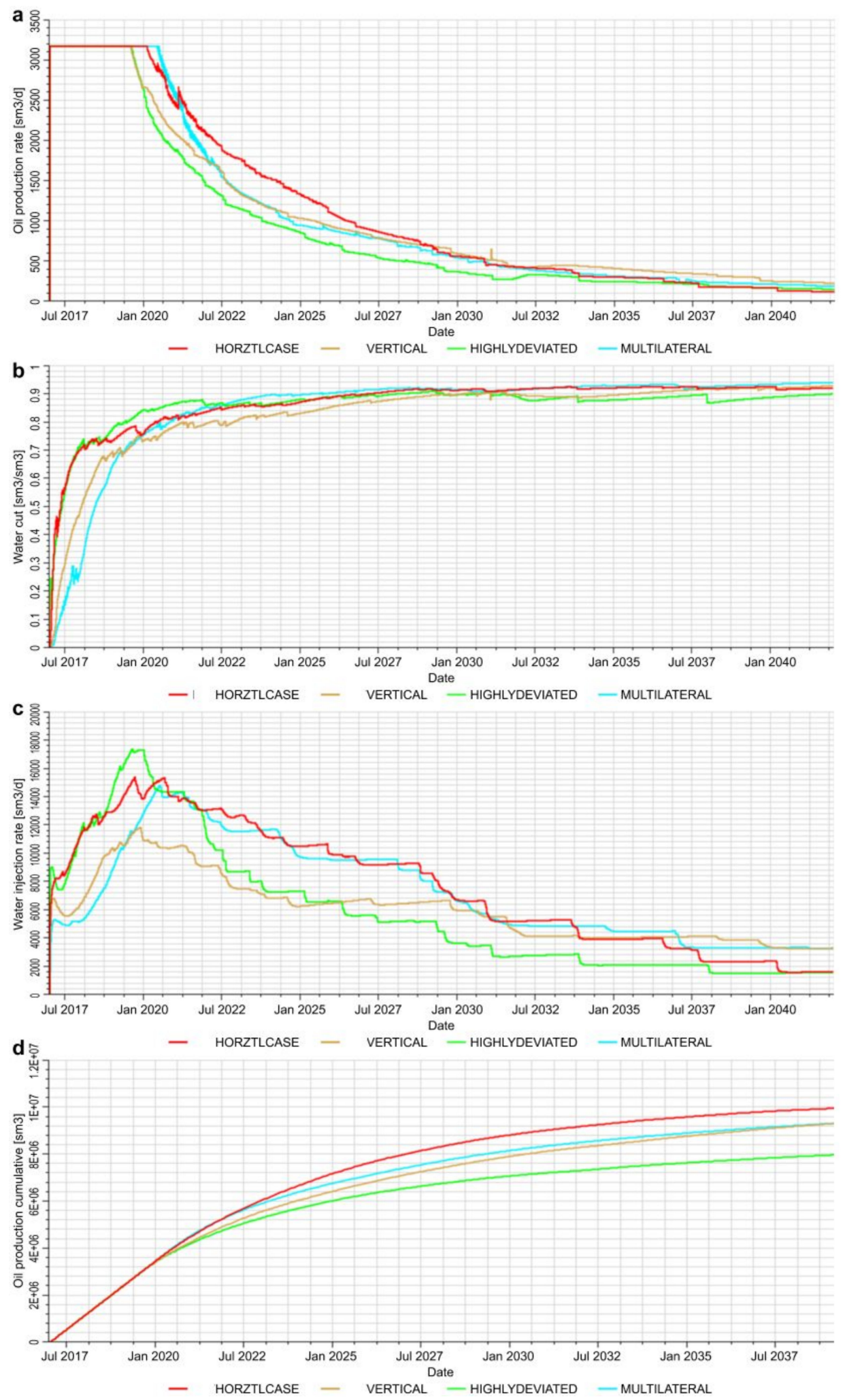

Figure 11. Production profile plots for the individual properties of each well type. (a) Oil production rate of each well type, (b) field water-cut ratio profiles of each well type, (c) field water injection rate profiles of each well type, and (d) field cumulative oil production of each well type. 


\subsubsection{Field Water-Cut}

Figure $11 \mathrm{~b}$ shows that the water-cut increased sharply in the four well types during the first three years of production. Subsequently, the water-cut in the vertical wells ( $72 \%$ of the maximum production) increased more slowly than in the horizontal and multilateral wells ( $78 \%$ of the maximum production), and the highest water-cut was observed in the highly deviated wells ( $80 \%$ of the maximum production). The total oil recovered at a $75 \%$ water-cut was highest in the horizontal wells, followed by the multilateral, vertical, and highly deviated wells. Hence, we infer that horizontal and multilateral wells will recover more oil than other well types. Highly deviated wells showed a higher water-cut than the other wells between 28 October 2018 and 24 December 2021. This was due to the structural setup of the reservoir, which enabled the inclined shape of the highly deviated wells to be in contact with more water zones than the oil-producing zones. However, by the end of the 25-year production period, the water-cut was similar between all the different well orientations $(94 \%)$.

\subsubsection{Field Water Injection Rate}

Highly deviated wells had the highest injection rate $\left(1.73 \times 10^{4} \mathrm{Sm}^{3} / \mathrm{d}\right)$, followed by the horizontal wells $\left(1.53 \times 10^{4} \mathrm{Sm}^{3} / \mathrm{d}\right)$. The multilateral wells reached their maximum injection rate $\left(1.47 \times 10^{4} \mathrm{Sm}^{3} / \mathrm{d}\right)$ after three years of waterflooding. The vertical wells had the lowest injection rate from the beginning of the waterflood, reaching a maximum of $1.16 \times 10^{4} \mathrm{Sm}^{3} / \mathrm{d}$ after two years of production (Figure 11c).

\subsubsection{Field Cumulative Oil Production}

The cumulative oil production for the first three years in all the four well types increased steadily at the same rate from the first day of production. However, on 6 April 2020, oil production began to deviate rapidly, increasing at different steady rates for each well type. After five years of production, both the multilateral and horizontal wells had identical cumulative oil productions $\left(5.783 \times 10^{6} \mathrm{Sm}^{3}\right)$, the vertical wells had a cumulative production of $5.55 \times 10^{6} \mathrm{Sm}^{3}$, and the highly deviated wells had the lowest cumulative production at $5.25 \times 10^{6} \mathrm{Sm}^{3}$. Oil production in the horizontal wells steadily increased and surpassed all the other well types as time elapsed. This reflects that the drilling of horizontal wells parallel to the reservoir bedding plane resulted in a wider area of connectivity with the oil-producing formation and led to improved drainage. On 12 November 2041, after 25 years of production, the horizontal wells showed a higher cumulative oil production $\left(1.012 \times 10^{7} \mathrm{Sm}^{3}\right)$ than the multilateral wells, which also produced oil at a higher rate than both the vertical and highly deviated wells. However, as shown in Figure 11d, the cumulative production in the vertical wells increased at a rapid rate with the production time. After 20 years of production, both the multilateral and vertical wells produced oil at the same rate $\left(9.192 \times 10^{6} \mathrm{Sm}^{3}\right)$, whereas the production rate remained the lowest for the highly deviated wells $\left(7.88 \times 10^{6} \mathrm{Sm}^{3}\right)$.

\subsection{Field Gas Production Rate}

The B27 reservoir is generally known to have low gas volumes. However, the highest maximum gas production for the four well types was observed in vertical wells $\left(1.52 \times 10^{5} \mathrm{Sm}^{3} / \mathrm{d}\right.$ on 6 July 2019). The multilateral, highly deviated, and horizontal wells had gas yields of less than $9.26 \times 10^{4} \mathrm{Sm}^{3} / \mathrm{d}$ (Figure 12). Gas production lasted for only 1 year from the start of production and then began to decrease sharply for all well types. 


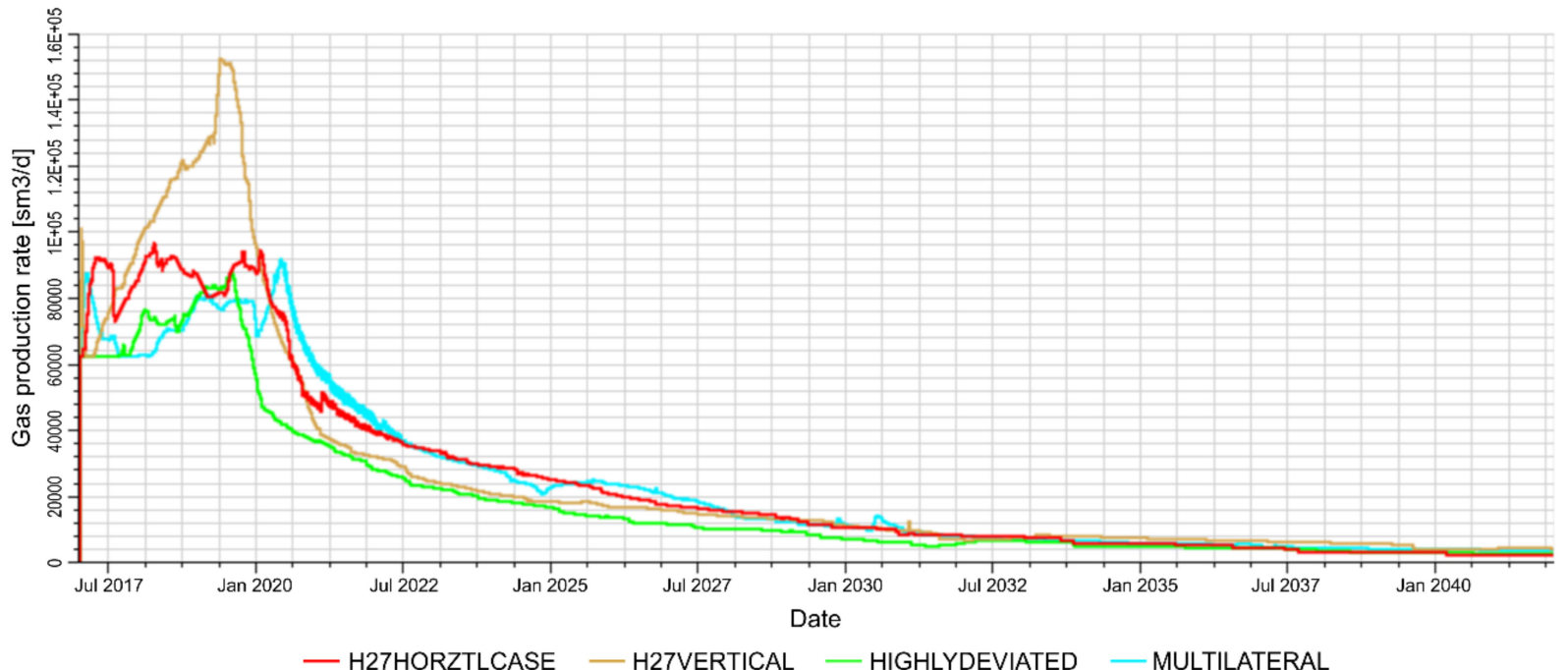

Figure 12. Field gas production rate for each well type.

\subsubsection{Field Water Production Rate}

The field water production rate increased steadily in all the well orientations right from the start of production until three years of the waterflood, when the maximum rates were obtained in all cases (Figure 13). The highly deviated wells were shown to have the highest water production rate of $1.42 \times 10^{4} \mathrm{Sm}^{3} / \mathrm{d}$ compared to multilateral, horizontal, and vertical wells, which had their maximum at $1.18 \times 10^{4} \mathrm{Sm}^{3} / \mathrm{d}, 1.17 \times 10^{4} \mathrm{Sm}^{3} / \mathrm{d}$, and $8.56 \times 10^{3} \mathrm{Sm}^{3} / \mathrm{d}$, respectively.

- $\begin{gathered}\text { HORZTLCASE } \\ \text { MULTILATERAL }\end{gathered}$

Field, Water production rate

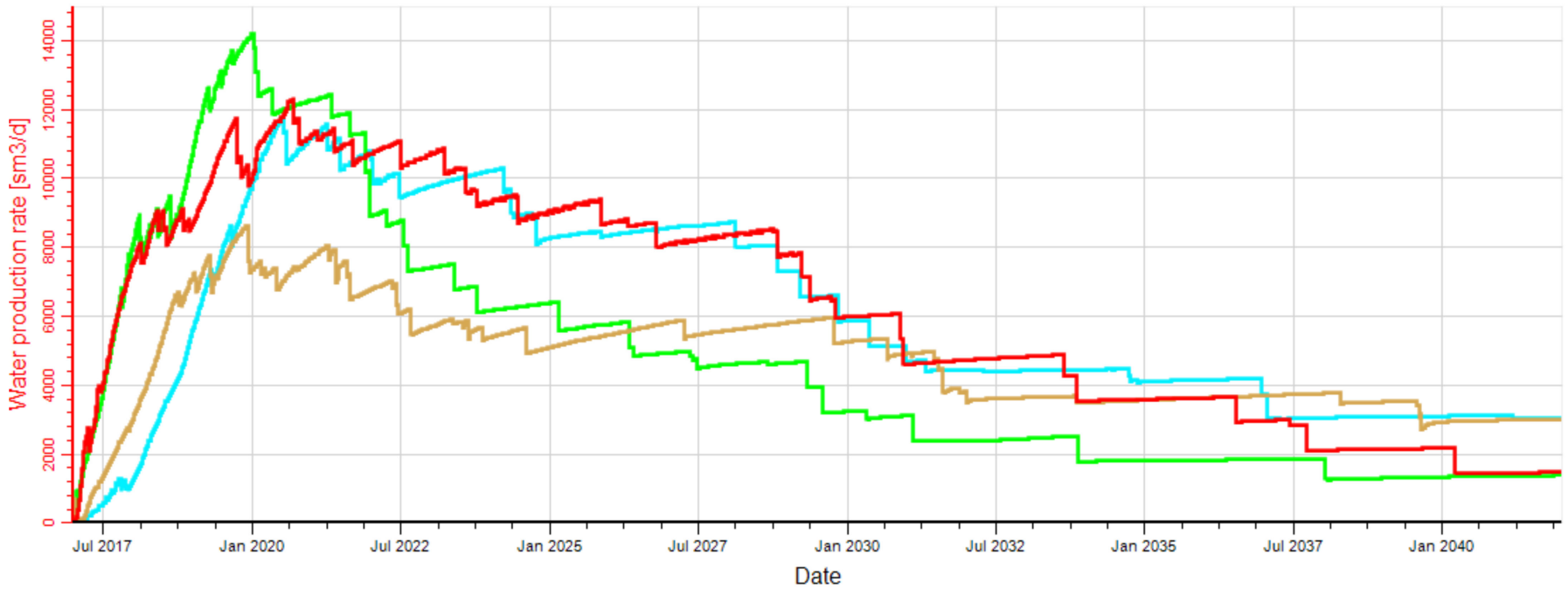

Figure 13. Field water production rate for each well type.

\subsubsection{Field Cumulative Water Production}

The cumulative water production in all the four well types increased steadily at the same rate from the first day of production (Figure 14). After the first three years, however, horizontal and highly deviated wells were exhibiting higher production than multilateral 
and vertical wells. By mid-July, 2020, the cumulative water production by horizontal wells increased more sharply than highly deviated wells. The deviated wells' production went on decreasing while the production in the other three well types was steadily increasing, with multilateral at a faster rate than the vertical wells. By July 2020, the production in horizontal wells was $3.5 \times 10^{7} \mathrm{Sm}^{3}$, while both multilateral and highly deviated wells had the same production at $3.0 \times 10^{7} \mathrm{Sm}^{3}$. Beyond this date, the multilateral water production increased rapidly, surpassing that of the highly deviated wells. Moreover, by the end of the production time, vertical wells had the least production followed by highly deviated wells. Meanwhile, horizontal wells had the highest cumulative water production at $5.0 \times 10^{7} \mathrm{Sm}^{3}$, then followed by multilateral $\left(4.5 \times 10^{7} \mathrm{Sm}^{3}\right)$.

- H27HORZTLCASE
MULTILATERAL

\section{Field, Water injection cumulative}

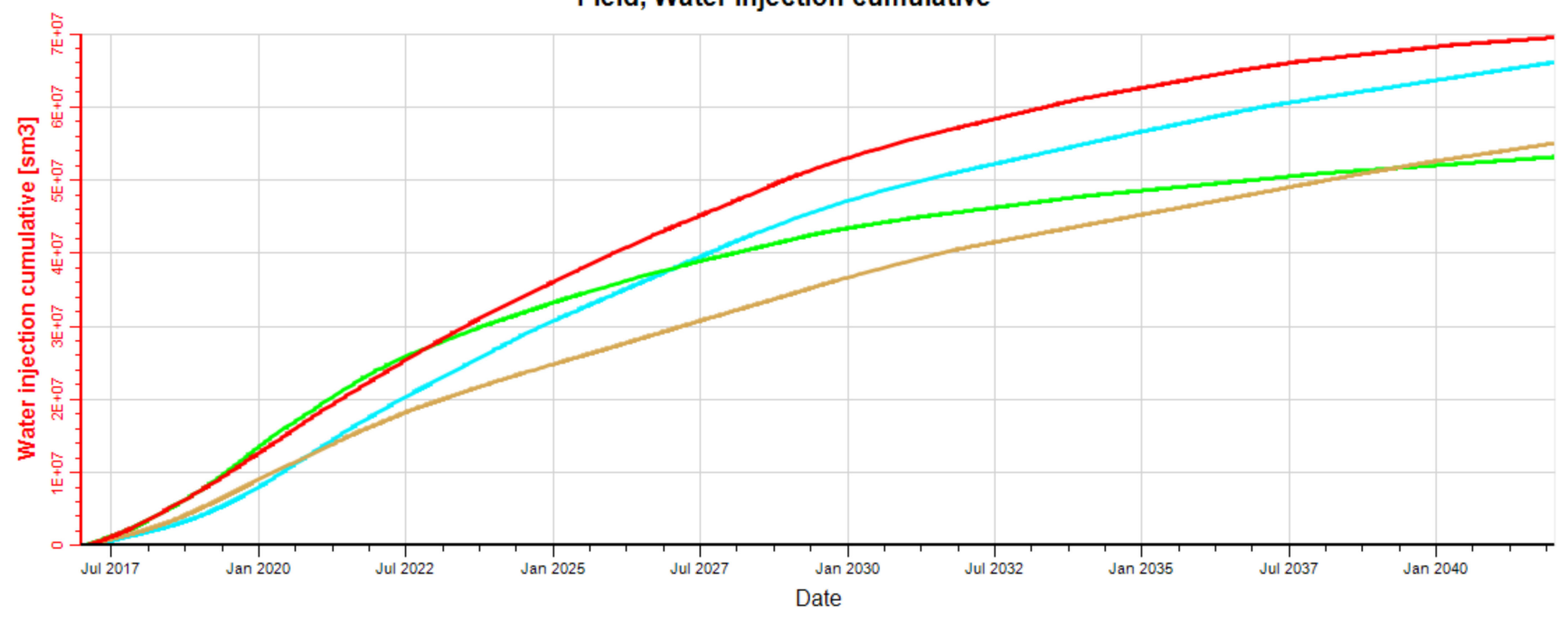

Figure 14. Field water production cumulative for each well type.

\subsection{Recovery Efficiency}

Identifying the recovery factor or recovery efficiency of different well orientations was the main objective of this study. We observed that recovery efficiency was identical (12\%) for all well types after three years of production (Figure 15). As oil production continued, there was a steady increase in the recovery efficiency for all well scenarios; however, there were important differences. For example, recovery from horizontal wells increased at a higher rate than that for all other well types, reaching a maximum of 33\% after 25 years of waterflooding. Multilateral wells had the next highest recovery, which was maintained for most of the waterflood period. However, after 20 years of production, both the vertical and multilateral wells exhibited the same recovery factor (31\%), which was maintained for the last five years of the waterflood. Highly deviated wells had the lowest recovery factor of all well types (26\%). The J1 Oilfield is a recent discovery with limited data and no historical data. Therefore, there remain numerous uncertainties in the oil-water and gas-oil contact sets. Hence, further investigations will be necessary after 3-5 years of active oil production. Moreover, while we acknowledge that numerous types of multilateral wells exist, here, we only considered dual lateral well types, given that they deliver better performance in shallow reservoirs [22]. 


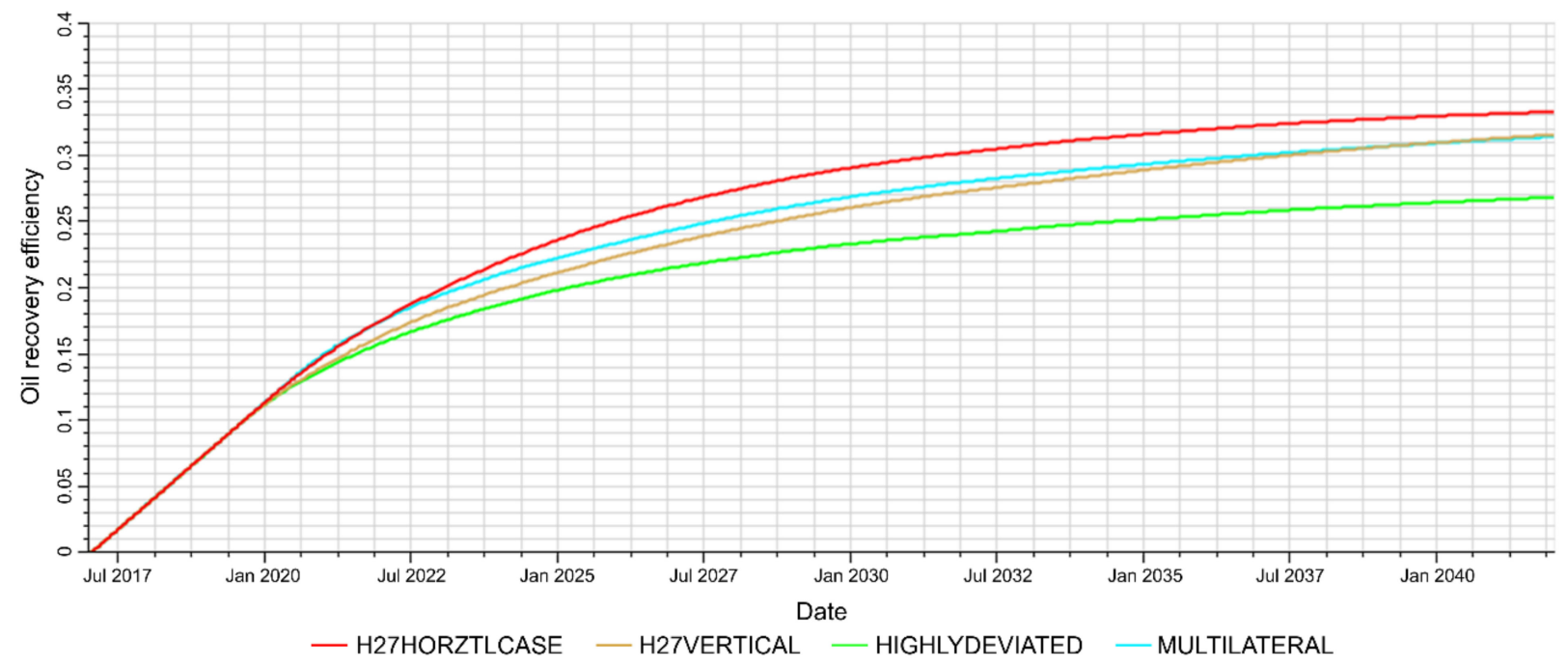

Figure 15. Oil recovery efficiency for each well type.

\subsection{Well Type Selection}

The selection of the well type to develop reservoirs is based on environmental impact, the oil recovery factor and cost to develop, and ability produce oil and gas. Our study confirms that horizontal and multilateral wells are not necessarily better than vertical or deviated wells for all reservoirs or vice versa. The application of different well types should be on a case-by-case basis. The cost difference (i.e., well drilling and the corresponding ongoing operating costs) should also be considered. Usually, the cost of a horizontal well is 1.5-3 times that of a vertical well, depending on its lateral length. The cost of multilateral wells depends on the number of laterals and the length of each lateral. As technology advances, it requires less rig time per well and lower related costs for materials, services, number of casings, and size of the wellbore, among other factors. The advancement of drilling technology has allowed drilling to target reservoirs using complicated well structures and measurements while also ensuring that the well trajectory remains with the target reservoir. These factors significantly reduce the uncertainty while drilling in areas with complex geological structures. In summary, the cumulative oil production, cost, and environmental impact are the dominant factors that affect the selection of the well type. It is necessary to conduct a thorough economic analysis before making a final decision. In this study, the difference in the oil recovery by four well types were small. Considering the higher well cost for horizontal wells and high environmental impact by vertical wells, we chose highly deviated wells for these green reservoirs locating in ecologically sensitive environments.

\subsection{Well Spacing}

Well spacing significantly affects the key indicators of the field development such as the rate of liquid and oil recovery from the reservoir, completeness of oil sweep out from the producing formation, the hydrocarbons' ultimate recovery factor, reservoir producing life, and a number of other indicators of development. Generally, small well spacing, which means more well numbers to develop the field, can accelerate oil production and increase recovery efficiency, but with the cost of higher investment and drop in net present value (NPV). Large well spacing that reduces well numbers to develop the field can lead to lower capital and operating costs, but with the expense of low production rate and low recovery factor. There is an optimum well spacing that can result in maximum NPV for project. It can be determined through a thorough study of field, design of well, simulation, production forecast, and economic analysis. 


\subsection{Economic Analysis}

In addition to the environmental impact, economics is another key factor when selecting the appropriate well type and well spacing. One critical indicator used in the project ranking is NPV. Generally, the well type that causes minimum environmental impact and maximum NPV should be chosen. Under the circumstance that several cases have similar $\mathrm{NPV}$, the one that has minimum environmental impact is ranked first. If environmental impact is equal, the case providing maximum NPV should be considered. The most complicated or difficult scenario is that there are two extreme cases, within which other cases lie. One extreme case has maximum NPV with maximum environmental impact, while another extreme case has minimum NPV with minimum environmental impact. Under this condition, the advantages and the disadvantages of each case should be scrutinized. A thorough review of environmental impact should be conducted, and a regulation agency should be consulted before any decision can made. The appropriate development plan can be chosen after a comprehensive evaluation of geology and engineering uncertainty, economic benefit, environmental and social impact, and geopolitical risk. NPV or rate of return (ROR) is often used in the economic analysis. To calculate NPV or ROR, revenue and cost are considered. Revenue is calculated from oil/gas price and production. In this work, productions of four well types were used. The cost includes exploration, development, production, and abandonment costs. Exploration cost includes the seismic acquisition, data processing, interpretation, geology analysis, experiment on rock and fluid, petrophysical and geophysical study, wildcat and appraisal well drilling and completion, well logging, and well test. Development cost consists of capital cost for drilling campaign for producer and injector, surface and subsurface facilities, and pipeline to transport oil-gas-water. Production cost can be divided into fixed operating cost and variable operating cost. Fixed operating cost will not vary significantly during the production while variable operating cost is proportional to the oil-gas-water production. For onshore fields, fixed operating cost can vary from $40 \%$ to $80 \%$ of total operating cost. For offshore fields, percentage of fixed operating cost is higher, from $50 \%$ to $90 \%$. Workover and/or well intervention service required to maintain production should be taken into account in production cost. Re-perforation cost is a part of operation cost, while deepening of existing wellbore to penetrate and produce deeper reservoir is classified as capital investment in a project. Abandonment cost is needed when reservoirs are depleted and the field ceases production or production is no long economic. The cost is to plug the wells and to restore the wellsite to original conditions. In addition to cost, some projects require the operator to pay a royalty to the mineral rights owner, which means the mineral rights owner can have a portion of hydrocarbon without paying any cost. This portion of production should be excluded in the gross revenue calculation. Net revenue then is calculated from the gross revenue and cost. Tax calculation is applied on the net revenue to obtain the after-tax cash flow. NPV is obtained by utilizing discounts rate. In this project, except for the size of the footprint (or environmental impact), hydrocarbon production and drilling completion cost were the main variables in the economic analysis of four well types in order to develop the target field. Through a systematically comprehensive evaluation of geology/reservoir, production, economic impact, and environmental impact, we found that highly deviated wells were the appropriate well type to produce in the studied field.

\section{Conclusions}

Few studies consider the application of this well type in the shallow green reservoirs of the Central and East African Rift Valley region. This is the first study of its kind in the region. We evaluated the performance of highly deviated wells, in comparison with three other well types. Horizontal wells had the highest cumulative oil production at 10.2 million $\mathrm{Sm}^{3}$, whereas other well types produced less than 9.5 million $\mathrm{Sm}^{3}$. The horizontal and multilateral wells yielded the highest oil production rates, whereas the lowest rates were observed for the highly deviated wells. Highly deviated wells were found to be an appropriate well type for non-communicating vertically non-concentrated 
stacked reservoirs or complex faulted reservoirs in this study, on the basis of reservoir simulation, production forecast, economic analysis, and environmental impact evaluation. This is because although the oil production from highly deviated wells is slightly lower than other cases, the footprint (environmental impact) is much smaller.

The study provides broad insights into the performance of various well types during waterflooding of green shallow heterogeneous reservoirs with vertical pressure disconnections, operated under similar operating conditions. For shallow reservoirs, multilateral wells are not always a suitable option because they have faster water breakthrough, increasing water production rates. Consequently, laterals may block fluid flow owing to vertical discontinuity. In such cases, the negative effect of reduced productivity owing to slanting outweighs the positive effect of increased reservoir thickness exposure. Additionally, multiple branches in shallow non-communicating zones may cause pressure fields around drain holes to interfere with each other, lowering the effective drawdown.

The results of this study provide a reference for reservoirs with unique characteristics, including those that are green, shallow, highly heterogeneous, and have complex faulted reservoirs with non-communicating pressure systems that require special production/injection plans characterized by very early injection. In shallow green reservoirs, water injection is implemented in the very early stages of field production. This imposes high risk to the reservoir as pressure has not been depleted, and unconsolidated to semi-consolidated reservoirs are easily fractured by waterflooding. This study illustrates a special case study for the successful development of a rare reservoir type. This is different from many other studies that model waterflooding during middle or later stages of oil production from moderate-depth or deep reservoirs. This research can be used as a reference for future research on similar reservoirs.

The observations from this study can aid in future decision-making and field development planning. Moreover, it serves as a successful practical example of the application of waterflooding as an initial recovery mechanism for green reservoirs, where oil is near the bubble point pressure. Before investment decisions are made for waterflooding in the J1 Oilfield, the operational costs associated with the well type that yields the highest oil recovery should be investigated. Thus, increasing oil recovery should not be the only prerequisite in economic/profitability analyses as is often the case in the selection of horizontal well configurations. Future studies should also examine other multilateral well types, particularly given the geological heterogeneity, structure, and location of the J1 oil reservoir. Moreover, as the J1 Oilfield is a recent discovery with no historical data, numerous uncertainties still exist in the oil-water and gas-oil contact sets. As such, further investigations will be necessary after 3-5 years of active oil production.

Author Contributions: Conceptualization, J.W. and C.X.; methodology, J.W. and K.L.; software, J.W.; validation, K.L., C.X., and J.W.; formal analysis, J.W.; writing-original draft preparation, J.W.; writing-review and editing, K.L. and J.W.; funding acquisition, C.X. All authors have read and agreed to the published version of the manuscript.

Funding: This work was supported by the Chinese Scholarship Council under the Ministry of Education, China. The funder had no role in the study design; the collection, analysis, and interpretation of data; the writing of the report; or the decision to submit the article for publication.

Institutional Review Board Statement: Not applicable.

Informed Consent Statement: Not applicable.

Data Availability Statement: The datasets generated during and/or analyzed during the current study are available from the corresponding author on reasonable request.

Acknowledgments: The authors are thankful to the oil and gas companies operating in the Lokichar Basin for providing data for the research. The authors are also grateful to the Key Laboratory of Tectonics and Petroleum Resources (China University of Geosciences, TPR-2019-10) and all individuals who provided the necessary technical support.

Conflicts of Interest: The authors declare no conflict of interest. 


\section{References}

1. International Association of Geophysical Contractors (IAGC). Importance of Fossil Fuels. Available online: https://www.iagc. org/importance-of-fossil-fuels.html (accessed on 13 June 2020).

2. Balasubramanian, S.; Chen, P.; Bose, S.; Alzahabi, A.; Thakur, G.C. Recent Advances in Enhanced Oil Recovery Technologies for Unconventional Oil Reservoirs. In Proceedings of the Offshore Technology Conference, Houston, TX, USA, 30 April 2018; Volume 3, pp. 1799-1805.

3. Islam, M.R. Emerging Technologies in Enhanced Oil Recovery. Energy Sources 1999, 21, 97-111. [CrossRef]

4. Ping, G.; Shasha, J.; Caizhen, P. Technologies and countermeasures for gas recovery enhancement. Nat. Gas Ind. B 2014, 1, 96-102. [CrossRef]

5. El-khatib, N.A.F. Waterflooding Performance in Inclined Communicating Stratified Reservoirs. SPE J. 2012, 17, 31-42. [CrossRef]

6. Ogbeiwi, P.; Aladeitan, Y.; Udebhulu, D. An approach to waterflood optimization: Case study of the reservoir X. J. Pet. Explor. Prod. Technol. 2018, 8, 271-289. [CrossRef]

7. Pourabdollah, K. Process Design of Cyclic Water Flooding by Real-Time Monitoring. J. Energy Resour. Technol. 2018, 140, 1-9. [CrossRef]

8. Rambaran, K.D.; Chin Chee Fat, S.T.; Layne, L.E. Exploiting Water Injection Techniques for Increasing Gas Recovery in Conventional Gas Reservoirs. In Proceedings of the SPE Trinidad and Tobago Section Energy Resources Conference, Port of Spain, Trinidad and Tobago, 25 June 2018; pp. 25-26.

9. Suleymanov, A.A.; Abbasov, A.A.; Guseynova, D.F.; Babayev, J.I. Oil reservoir waterflooding efficiency evaluation method. Pet. Sci. Technol. 2016, 34, 1447-1451. [CrossRef]

10. Wang, Y.; Hou, J.; Tang, Y.; Song, Z.; You, Z. Application of modified Dykstra-Parsons method to natural bottom-water drive in non-communicating fractured-vuggy reservoir. J. Pet. Sci. Eng. 2018, 167, 682-691. [CrossRef]

11. Crawford, P.B. Factors Affecting Waterflood Pattern Performance and Selection. J. Pet. Technol. 1960, 12, 11-15. [CrossRef]

12. Tang, G.; Xue, L.; Zhou, T.; He, S.; Song, M.; Li, Y. Study on Influencing Factors of Heavy Oil Waterflooding Development. IOP Conf. Ser. Earth Environ. Sci. 2019, 300, 022086. [CrossRef]

13. Yazdani Sadati, E.; Sahraei, E. An experimental investigation on enhancing water flooding performance using oil-in-water emulsions in an Iranian oil reservoir. J. Pet. Explor. Prod. Technol. 2019, 9, 2613-2624. [CrossRef]

14. Salas, J.R.; Clifford, P.J.; Jenkins, D. SPE 35711 Multilateral Well Performance Prediction. West. Reg. Meet. 1996. [CrossRef]

15. Tabatabaei, M.; Ghalambor, A. A New Method to Predict Performance of Horizontal and Multilateral Wells. SPE Prod. Oper. 2011, 26, 75-87. [CrossRef]

16. Bouchaala, A.; Jaber, N.; Yassine, O.; Shekhah, O.; Chernikova, V.; Eddaoudi, M.; Younis, M. Nonlinear based MEMS sensors and active switches for gas detection. Sensors 2016, 16, 758. [CrossRef]

17. Ren, Y.; Wang, N.; Jiang, J.; Zhu, J.; Song, G.; Chen, X. The Application of Downhole Vibration Factor in Drilling Tool Reliability Big Data Analytics-A Review. ASCE-ASME J. Risk Uncert. Engrg Sys. Part B Mech Engrg. 2019, 5, 1-11. [CrossRef]

18. Wang, X.; Chen, P.; Huang, W.; Zou, J. Development of torque clutch drilling tool and evaluation of drag reduction performance. Adv. Mech. Eng. 2018, 10, 1-20. [CrossRef]

19. Zhang, G.; Liu, M.; Shen, N.; Wang, X.; Zhang, W. The Development of the Differential MEMS Vector Hydrophone. Sensors 2017, 17, 1332. [CrossRef] [PubMed]

20. Edwards, S. Is Waterflooding the Clearfork Viable? Using Reservoir Simulation and Analog Data to Overcome High Uncertainty. In Proceedings of the SPE Annual Technical Conference and Exhibition, San Antonio, TX, USA, 9 October 2017 ; pp. 1-10.

21. Pieters, D.A.; Al-Khalifa, A.J. Horizontal Well Performance in a Layered Carbonate Reservoir. In Proceedings of the Low Permeability Reservoirs Symposium, Denver, CO, USA, 15 April 1991; pp. 15-17.

22. Elyasi, S. Assessment and evaluation of degree of multilateral well's performance for determination of their role in oil recovery at a fractured reservoir in Iran. Egypt. J. Pet. 2016, 25, 1-14. [CrossRef]

23. Ekebafe, A.O.; Tobechukwu, E.; Skaioye, O.T.; Raymond, L. Horizontal matrix injector stimulation in unconsolidated sand. In Proceedings of the SPE Nigeria Annual International Conference and Exhibition, NAIC 2019, Lagos, Nigeria, 5 August 2019; pp. 5-7.

24. Muradov, K.; Prakasa, B.; Davies, D. Extension of Dykstra-parsons model of stratified-reservoir waterflood to include advanced well completions. SPE Reserv. Eval. Eng. 2018, 21, 703-718. [CrossRef]

25. Zadravec, D.; Brkić, V. Intelligent natural dump flooding well—Case study from the area of the western Persian/Arabian Gulf and possible application in the Croatian mature oil field Beničanci. The Mining-Geology-Petroleum Engineering Bulletin. Rud.-Geološko-Naft. Zb. 2020, 35, 21-31. [CrossRef]

26. Algharaib, M. The efficiency of horizontal and vertical well patterns in waterflooding: A numerical study. In Proceedings of the SPE Mid-Continent Operations Symposium, Oklahoma City, OK, USA, 28 March 1999; pp. 28-31.

27. Almedeij, J.H.; Algharaib, M.K. Influence of sand production on pressure drawdown in horizontal wells: Theoretical evidence. J. Pet. Sci. Eng. 2005, 47, 137-145. [CrossRef]

28. Shi, H.; Hu, Y.; He, Y.; Sun, Q.; Zhao, J.; Oil, O. Case Stories of Horizontal Wells in Offshore Fluvial Oil Reservoir. In Proceedings of the International Petroleum Technology Conference, Beijing, China, 22 March 2019; pp. 26-28.

29. Taber, J.J.; Seright, R.S. Horizontal Injection and Production Wells for EOR or Waterflooding. In Proceedings of the Permian Basin Oil and Gas Recovery Conference, Midland, TX, USA, 18 March 1992. 
30. Temizel, C.; Purwar, S.; Abdullayev, A.; Urrutia, K. Optimization of Production in Slanted Horizontal Wells in Tight Reservoirs. In Proceedings of the SPE Reservoir Characterisation and Simulation Conference and Exhibition, Abu Dhabi, United Arab Emirates, 14 September 2015; pp. 14-16.

31. Ayokunle, A.T.; Hashem, M.H. Design optimization of multilateral wells in heterogeneous reservoirs. In Proceedings of the SPE 182764, SPE Kingdom of Saudi Arabia Annual Technical Symposium and Exhibition, Dammam, Saudi Arabia, 25 April 2016; pp. 25-28.

32. Delamaide, E. Waterflooding heavy oil reservoirs with horizontal wells: Field examples from Canada. SPE-192087-MS. In Proceedings of the SPE Asia Pacific Oil and Gas Conference and Exhibition 2018, APOGCE 2018, Brisbane, Australia, 23 October 2018; pp. 23-25.

33. Ferreira, H.; Technologies, P.I.; Mamora, D.D.; Startzman, R.A.; Texas, A. SPE 35208 Simulation Studies of Waterflood Performance with Horizontal Wells. In Proceedings of the Permian Basin Oil and Gas Recovery Conference, Midland, TX, USA, 27 March 1996; pp. 529-534.

34. Jiang, T.; Zhang, H.; Wang, H.; Yin, G.; Yuan, F.; Wang, Z. Geomechanical approach lead to successful Implementation of the first highly deviated well at kuqa depression in Tarim Basin. In Proceedings of the International Petroleum Technology Conference, Beijing, China, 22 March 2019.

35. Mahmood, S.; Salazar, P.; Zhao, X.; Pointing, M.; Sayed, A. Waterflooding in Giant Carbonate Reservoir; Successes and Challenges. In Proceedings of the Abu Dhabi International Petroleum Exhibition \& Conference, Abu Dhabi, United Arab Emirates, 13 November 2017; pp. 13-16.

36. Mukanov, A.; Kenzhetayev, A.; Kamashev, A.; Kozlov, Y. Tight Sandstone Reservoir Waterflooding Efficiency Study. In Proceedings of the SPE Annual Caspian Technical Conference \& Exhibition, Astana, Kazakhstan, 1 November 2016; pp. 1-3.

37. Ozkan, E.; Raghavan, R. A Breakthrough Time Correlation for Coning Toward Horizontal Wells. Eur. Pet. Conf. 1990. [CrossRef]

38. Ranjith, R.; Suhag, A.; Balaji, K.; Putra, D.; Dhannoon, D.; Saracoglu, O.; Hendroyono, A.; Temizel, C.; Aminzadeh, F. Production Optimization Through Utilization of Smart Wells in Intelligent Fields. In Proceedings of the SPE Western Regional Meeting, Bakersfield, CA, USA, 23 April 2017.

39. Tiercelin, J.J.; Potdevin, J.L.; Morley, C.K.; Talbot, M.R.; Bellon, H.; Rio, A.; Le Gall, B.; Vétel, W. Hydrocarbon potential of the Meso-Cenozoic Turkana Depression, northern Kenya. I. Reservoirs: Depositional environments, diagenetic characteristics, and source rock-reservoir relationships. Mar. Pet. Geol. 2004, 21, 41-62. [CrossRef]

40. Macgregor, D. Tectonics and Petroleum Systems of East African Rifts. In Proceedings of the Second EAGE Eastern Africa Petroleum Geoscience Forum, Kampala, Uganda, 22-24 November 2016.

41. Morley, C. Marked along-strike variations in dip of normal faults-The Lokichar fault, N. Kenya rift: A possible cause for metamorphic core complexes. J. Struct. Geol. 1999, 21, 479-492. [CrossRef]

42. Ibrahim, M.M.; Abdulaziz, A.M.; Fattah, K.A. STOIIP Validation for a heterogeneous multi-layered reservoir of a mature field using an integrated 3D geo-cellular dynamic model. Egypt. J. Pet. 2018, 27, 887-896. [CrossRef]

43. Luzón, A.; González, A.; Muñoz, A.; Sánchez-Valverde, B. Upper Oligocene-lower Miocene shallowing-upward lacustrine sequences controlled by periodic and non-periodic processes (Ebro Basin, northeastern Spain). J. Paleolimnol. 2002, 28, 441-456. [CrossRef]

44. Soto, R.; Larrasoaña, J.C.; Beamud, E.; Garcés, M. Early-Middle Miocene subtle compressional deformation in the Ebro foreland basin (northern Spain); insights from magnetic fabrics. C. R. Geosci. 2016, 348, 213-223. [CrossRef]

45. Battashi, F.; Khattak, A.; Svec, R.; Development, P.; Llc, O. SPE-193716-MS Fluid Contact Identification for a Heavy Oil Shaly Sand Reservoir with a Biodegraded Oil Column. In Proceedings of the SPE International Heavy Oil Conference and Exhibition, Kuwait City, Kuwait, 10 December 2018.

46. Vrolijk, P.; James, B.; Myers, R.; Maynard, J.; Sumpter, L.; Sweet, M.; Upstream, E. SPE 93577 Reservoir Connectivity AnalysisDefining Reservoir Connections and Plumbing. In Proceedings of the SPE Middle East Oil and Gas Show and Conference, Manama, Kingdom of Bahrain, 12 March 2005.

47. Uchida, M.; Salahuddin, A.A.; Ashqar, A.; Awolayo, A.N.; Olayiwola, S.O.; Eissa al Hammadi, K. Evaluation of Water Saturation in a Low-Resistivity Pay Carbonate Reservoir Onshore Abu Dhabi: An Integrated Approach. In Proceedings of the Abu Dhabi International Petroleum Exhibition and Conference, Abu Dhabi, United Arab Emirates, 9 November 2015. [CrossRef]

48. Ashqar, A.; Uchida, M.; Salahuddin, A.A.; Olayiwola, S.O.; Awolayo, A.N. Evaluating a Complex Low-Resistivity Pay Carbonate Reservoir Onshore Abu Dhabi: From Model to Implementation. In Proceedings of the Abu Dhabi International Petroleum Exhibition \& Conference, Abu Dhabi, United Arab Emirates, 7 November 2016. [CrossRef]

49. Buckley, S.E.; Leverett, M.C. Mechanism of Fluid Displacement in Sands. Trans. AIME 1942, 146, 107-116. [CrossRef]

50. Kasap, E. Estimating kv/kh Ratio for Conductive and Nonconductive Shales and Mudstones. In Proceedings of the SPE-68782-MS, SPE Western Regional Meeting, Bakersfield, CA, USA, 26 March 2001.

51. David Orodu, O.; Tang, Z.; Fei, Q. Application of prediction models to performance of high paraffinic content oilfields: Case study Shen95 Block of Jinganbao Oilfield. J. Pet. Sci. Eng. 2009, 68, 223-234. [CrossRef]

52. Wang, Y.; Li, G.; Reynolds, A.C. Estimation of Depths of Fluid Contacts by History Matching Using Iterative Ensemble-Kalman Smoothers. SPE J. 2010, 15, 509-525. [CrossRef]

53. Zhang, S.; Liu, Z.; Shi, A.; Wang, X. Development of accurate well models for numerical reservoir simulation. Adv. Geo-Energy Res. 2019, 3, 250-257. [CrossRef] 
54. Adamu, M.B.; Sulaiman, A.D.I.; Shamsudeen, A.A.; Auwalu, A.I. Optimization of waterflooding patterns in multilateral wells: A numerical simulation approach. Int. J. Sci. Eng. Res. 2015, 6, 10-17.

55. Jafar, A.S.; Al-Attar, H.H.; El-Ageli, I.S. Discussion and comparison of performance of horizontal wells in Bouri field. Proc. Eur. Pet. Conf. 1996, 2, 465-473. [CrossRef]

56. Lei, Z.; Li, J.; Deng, X.; Tang, Z.; Yu, T.; Zhang, Z.; Yang, L. A Performance analysis model for multi fractured horizontal wells in tight oil reservoirs. In Proceedings of the International Petroleum Technology Conference, Bangkok, Thailand, 12 November 2016.

57. Algharaib, M.; Gharbi, R. The performance of water floods with horizontal and multilateral wells. Pet. Sci. Technol. 2007, 25, 995-1012. [CrossRef]

58. Shadizadeh, S.R.; Kargarpour, M.A.; Zoveidavianpoor, M. Modeling of inflow well performance of multilateral wells: Employing the concept of well interference and the Joshi's expression. Iran. J. Chem. Chem. Eng. 2011, 30, 119-133. 